$1-1-1940$

\title{
Epistle to the Farm : The Report of the Director, West Virginia Agricultural Experiment Station, Morgantown, for the Biennium 1938 to 1940
}

C. R. Orton

Follow this and additional works at: https://researchrepository.wvu.edu/ wv_agricultural_and_forestry_experiment_station_bulletins

\section{Digital Commons Citation}

Orton, C. R., "Epistle to the Farm : The Report of the Director, West Virginia Agricultural Experiment Station, Morgantown, for the Biennium 1938 to 1940" (1940). West Virginia Agricultural and Forestry Experiment Station Bulletins. 298.

https://researchrepository.wvu.edu/wv_agricultural_and_forestry_experiment_station_bulletins/299 @ WVU. It has been accepted for inclusion in West Virginia Agricultural and Forestry Experiment Station Bulletins by an authorized administrator of The Research Repository @ WVU. For more information, please contact ian.harmon@mail.wvu.edu. 
West Virginia University Libraries

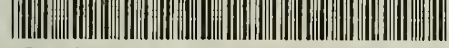
308021008961253 

Epistle to the 7 arm

BY C. R. ORTON

The Report of the Director, West Virginia Agricultural Experiment Station, Morgantown, for the Biennium 1938 to 1940 (Bulletin 298 December 1940) 


\section{THE AGRICULTURAL EXPERIMENT STATION}

\section{of \\ WEST VIRGINIA UNIVERSITY \\ Morgantown}

December 15, 1940

To the West Virginia Farmer:

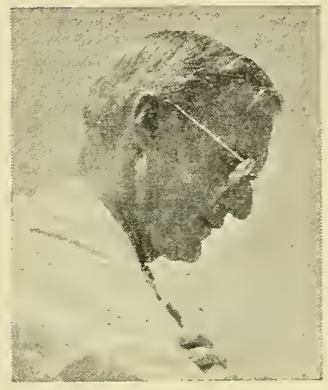

Two years ago, I wrote my first Epistle. The response that has come to me from all sources encourages me to write this second one. It tells what we at the Agricultural Experiment Station are trying to do in your behalf.

You will find that a large number of pieces of research are undertaken here, and perhaps you are asking yourself, "Why should there be so many lines of research?"

For this we have only one answer:

We have to plug as many of the holes as we can, as fast as we can find them.

I don't have to tell you that farming is a highly complicated business. There are many chances for leaks, and it is our business here to find out how to stop them.

One of those leaks is the result of the action of rainwater. This business of conserving water is an important one, and this Experiment Station is doing its level best to find how to make water behave in such a way that it will fulfill its mission without tearing $u p$ the land.

And what of the future? The outcome of the war abroad is going to have much to do in reshaping America's farm enterprises. There again, the Experiment Station will have to lead the way.

Finally, let me call your attention to the end of this Epistle, where I try to bring out some of the important needs of the Station.

I wish you pleasure in reading this bulletin. You'll like it best if you take it on the installment plan.

Believe me, yours,

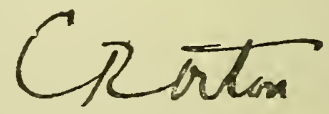

Director. 
Our soils and our pastures What makes soil slip? . . . . . . . . . . . . . 5

How rebuild eroded soils? . . . . . . . . . . . . 6

Alfalfa thrives on lime . . . . . . . . . . . . 8

Growers are taking to hybrid corn . . . . . . . . . 9

Not all rootstock combinations will work out . . . . . 13

Sooty apples . . . . . . . . . . . . . . . . . 14

Increasing the color of apples on the twig . . . . . . 14

Potatoes respond to complete fertilizer . . . . . . . 15

Two versus one tomato plant per stake . . . . . . 16

Rye and vetch for green manures . . . . . . . . . 17

Pastures for finishing yearling steers and heifers . . . . 17

First-cross Corriedale ewe for wool and mutton . . . 18

Left and right may not be the same . . . . . . 20

What protein for your battery chick ration? . . . . . 20

There is no pasture like bluegrass . . . . . . . . . 23

Can feed have any bearing on garget? . . . . . . . 24

The progeny test can predict butterfat percentage . . 25

Fruit and leaf injury from spraying . . . . . . 26

What causes potato blue stem? . . . . . . . . 27

Vitamin $\mathrm{A}$ and the common cold . . . . . . . 27

Ants vs. codling moths . . . . . . . . . . . . . 28

What about non-poisonous sprays? . . . . . . . 29

Cooperative buying in West Virginia . . . . . . . . 29

Pasture improvement in an experimental county program 31

A new service to forest landowners . . . . . . . . 32

Different trees, different litters . . . . . . . . 34

Publications of the biennium 1938-1940 . . . . . . . 37

1 


\section{FARM CROPS AND SOILS*}

\section{Our Soils and Our Pastures}

We have proved to our satisfaction that topdressings of lime and superphosphate are the most profitable ways of improving West Virginia pastures.

At Morgantown, for instance, on a Dekalb silt loam, phosphorus and lime applied in 1930 and 1932 were still showing beneficial results in 1940. Some of these plots were treated again in 1937 and these showed greater yields than the plots that had no attention since 1932.

Where phosphorus and lime, or phosphorus, potash, and lime, or nitrogen, phosphorus, potash, and lime was applied on those early plots, the result has been from 20 to 30 percent of desirable species of herbage. The check plots receiving no fertilizer or lime showed only 1 percent of desirable herbage.

It seems that, in the long run, an application of lime and fertilizer won't last forever. You've got to renew it if you want good pastures. But how often? That's what F. W. Schaller and G. G. Pohlman are working on now, on three different soil types in the state.

And in cooperation with the Soil Conservation Service, the West Virginia Station now has begun experiments on eight soil types in various parts of the state, to determine the effect of contour pasture furrows on the amount and type of vegetation produced over a period of years, along with the amount and distribution of soil moisture. The efficiency and economy of contour furrows will be compared with other approved pasture management practices. A great deal of good should come out of this research.

Pastures are the most important crop we have. Everybody with cattle or sheep stands to gain when pastures are made more productive. On them depends the maintenance of our beef and dairy cattle, sheep, and wool. Yet their decline in productiveness through the years has been an important factor in reducing farmer income.

At Lewisburg our animal husbandmen have carried out extensive experiments which convince us that pastures afford the most economical means of producing an animal unit. Under a proper system of fertilizing and management we have learned that a pound of beef or lamb can be produced much more cheaply by pasture than through a system of grain feeding.

- The material in this Epistle was compiled by the Editor. 


\section{What Makes Soil Slip?}

As a nation, we are just beginning to realize the importance of soil water and its relation to ground water. We used to think that what we call the water table was built up from the depths, and that rainfall simply helped to maintain the top at a certain level. The more the rain, the higher the top of this mountain of water.

Well, we've changed our minds.

The West Virginia. Station has been studying this business of underground waters and soil slips since 1938 . In all but ten southern counties, S. L. Galpin has carried on investigations of the conditions that make for slips. In describing soil we divide it into layers or zones. The A zone is the usual topsoil, and B is the subsoil. From there it goes into $\mathrm{C}$ and finally $\mathrm{D}$, which is next to bedrock. The A zone, of course, is the one that carries most of the organic matter.

To find ont something of the arrangement and depth of soil zones, and of the distribution of water within and around slips, we used special borers and got cores of soil in the different layers. The soil from about 100 cores was taken to the laboratory and examined chemically and mechanically. And here's what we found:

The thickness of soil layers from surface to bedrock varied from five to more than twelve feet. Bedrock was shale, usually impervious. Inpervious layers of high clay content were encountered within the subsoil, and at times these were closely associated with pervious, silty layers. Now the silty layers were often found to be saturated with water and as soft as mud. 'This layering within the subsoil is largely inherited from the rock strata from which the soil is forming. As a result the layers tend to be nearly level, and as you go further downhill, they come closer to the surface.

Now let's go back to one of the slips where we got those soil cores. What apparently has happened is that, during and after a prolonged rain, the water tried to penetrate down to bedrock, but was arrested by the impervious clay in the lower zones. As the water accumulated, it built up what we know as a hydraulic head, which means that it has pressure-up as well as down. Above this "captive" water, the ground is already well soaked. It takes several days for all this to take place as the rainwater trickles down to the Layer Impervious. The "captive" water presses out in all directions. Downhill the hydraulic head is greater and the weight of overlying soil often is less. What an opportunity! A little more water pressure from above, below, and behind, - -and a body of soil slips out of place! 
Now as to the theory of water conservation. Rain that doesn't run off the surface percolates into the soil. Some returns to the air by evaporation and transpiration, some reaches bedrock, and if the rock is porous or has cracks, the water goes down farther and returns to the surface in springs. If the land is hilly, much of the water trickles slowly through the soil and, because of impervious or water-soaked layers, it reaches the surface again, somewhere downhill. In these ways the little waters from countless points gather into creeks and so replenish the rivers. It is a continuous cycle. The earth, especially the topsoil, acts as a reservoir between rains. If rainfall is lacking, the reservoir must give up some or all of its supply. If rainfall is too plentiful, too much water gets into the land, or it runs off the surface to cause erosion and overflow our streams.

The presence of trees and other vegetation serves to equalize the gain and loss of water from the soil. Trees also serve to anchor the soil. Plant roots capture and redistribute huge quantities of water, partly through transpiration by leaf, partly through directing water downward or whichever way the roots lead. Decaying vegetation in the soil greatly increases its water-holding capacity. Man's way of controlling the earth's reservoir is primarily by controlling the receptiveness of topsoil to water and also the capacity to hold water.

Our national problem in this water business is

To catch the drop of water where it falls

and

To redirect that drop where it is needed most.

\section{How Rebuild Eroded Soils?}

Through erosion, the great bulk of farmland in West Virginia has suffered the loss of at least one-fourth of its topsoil. Indeed, more than 4 million acres have lost more than three-fourths of their topsoil. As long as nothing is done to arrest it, the situation will continue to get worse.

But the Experiment Station is well aware of the problem. In 1937 we published the first report on land classification. Since 1939 we have begun intensive long-time research in the hunt for a suitable cover that will form a new topsoil for future generations. We may have to support in the future many more people on the land than we do now. We must be able to show these people how to form topsoil from subsoil on these eroded lands. Nature did it over long periods of time but man should be able to shorten the process, and that's what we want to do. 
Over on the Reymann Memorial Farms in Hardy County on a shale soil we established seedings of grasses, legumes, and trees. A satisfactory stand was obtained in all cases. Tall oatgrass and sweet clover were outstanding from the standpoint of producing a cover during the first year. In the other seedings of grasses and legumes, more weeds showed up. And unplowed areas that were treated with lime and fertilizer showed improved growth of all sorts.

At Wardensville, too, we planted 18 quarter-acre forest plots with hardwood and softwood seedlings. These included red pine, shortleaf pine, tree of heaven, poplar, black locust, green ash, red oak, and black walnut, alone or in combinations of two of these species. We have long to wait before we can give definite recommendations on desirable species, but we can already report on some fertilizer trials with these trees, and that is this: Fast-growing trees are remarkably benefited by fertilizer, but with the slow type, like red pine, the seedling trees are actually suppressed by weeds coming in on the richer soil.

That's our experience at Wardensville. We are thinking of expanding this important study by taking in other soil types. In spring, 1941, we plan to set up a similar experiment on the land-utilization project near Point Pleasant. Those working on the project include G. G. Pohlman, W. M. Broadfoot, W. C. Pereival, Torkel Holsoe, and G. M. Browning.

\section{Limestone Soils Are Best for Deep-Rooted Plants}

If you have been at any of our field days at Morgantown, you have seen those colonies of tile standing on edge, with growths of different sorts in their 2-foot craters.

In this experiment our aim is to see what effect the vertical distribution of lime has on plants like alfalfa, with roots that go deep. Fortytwo tile plots were limed on the 0 to 8 -inch, the 8 to 16 -inch, and the 16 to 24-inch layers. G. G. Pohlman, T. C. McIlvaine, and W. M. Broadfoot found that putting lime in the lower horizons, especially the 16 to 24 -inch layer, gave very substantial increases in yield-something like $2 \frac{1}{2}$ tons to the acre.

That is half the story. The other observation that we can report is that the distribution of nodules on the roots of alfalfa is most numerous where lime is present in sufficient quantities.

So far, of course, there is no practical way of getting lime into the lower layers of soil in the open field. But this experiment goes to show that soils of limestone origin have an advantage in supporting deeprooted, lime-loving plants like alfalfa, because the lime is available in the lower horizons. 


\section{Alfalfa Thrives on Lime}

In my 1938 Epistle I told you that alfalfa needs lime first of all; then fertilizer. The experiences of G. G. Pohlman and W. M. Broadfoot since then give further weight to that statement.

Where we limed, we got increases in alfalfa yield of three-fourths to $11 / 2$ tons per acre, compared with fields where we used only superphosphate and potash. Even on soils of limestone origin, we had 2870 pounds more alfalfa per acre when we limed.

Thereafter, applications of phosphorus and potash gave substantial increases in yields-something like a half ton per acre. The practical limits seemed to be 500 pounds of 20 percent superphosphate and 100 pounds of potash per acre.

I repeat the observation made two years ago, when first cuttings were found to be lower in phosphorus than later cuttings. Our experiments on different soil types also tell us that alfalfa on certain soils in the state may have a lower content of phosphorus than is necessary in hay to prevent phosphorus deficiency in livestock.

\section{What Varieties for Your Farm Crops?}

Two years ago I reported that winter barley should be seeded two or three weeks before wheat is sown. Since then our experiences at Morgantown, Kearneysville, and Lakin have reaffirmed that report. The latest date that barley can safely be sown in those areas is about two weeks before wheat seeding.

The acreage planted to barley in West Virginia is on the increase and there is a demand for the so-called "smooth" varieties. These smooth or hooded types have not yielded as well, and they haven't produced as high-quality seed as the bearded varieties. But we do have several promising hooded selections which may be able to compete with the bearded type.

There is a time in April beyond which oats should not be planted without risking lower yields. So far, April 14 seems to be the deadline at Morgantown.

After three years of trials R. O. Weibel and E. J. Wellhausen find that by applying up to 200 pounds per acre of nitrogen topdressing, the yield of winter wheat can be increased, if the fertilizer is applied when wheat is about ten inches high.

Perhaps a summary of the results we've had in our variety tests in recent years will be helpful. 


\begin{tabular}{|c|c|c|c|c|c|}
\hline Place Grown & Crop & $\begin{array}{l}\text { Numbe } \\
\text { Variet } \\
\text { or Sel } \\
\text { tions T }\end{array}$ & & $\begin{array}{l}\text { Number of } \\
\text { Years for } \\
\text { Test } \\
\text { Reported }\end{array}$ & $\begin{array}{l}\text { Highest-Yielding } \\
\text { Varieties or Strains }\end{array}$ \\
\hline Morgantown & $\begin{array}{l}\text { Winter } \\
\text { Barley } \\
\text { Winter }\end{array}$ & (var.) & 21 & 5 & $\begin{array}{l}\text { Kentucky No. 1, Scot- } \\
\text { tish Pearl, Folk }\end{array}$ \\
\hline Morgantown & $\begin{array}{l}\text { Barley } \\
\text { Winter }\end{array}$ & (sel.) & 26 & 4 & $\begin{array}{l}\text { I- } 34-127, \quad \mathrm{I}-35-33 \\
\quad \mathrm{I}-34-136\end{array}$ \\
\hline Arthurdale & $\begin{array}{l}\text { Barley } \\
\text { Winter }\end{array}$ & (var.) & 18 & 2 & $\begin{array}{l}\text { Orel, Tenn. No. 5, } \\
\text { Scottish Pearl }\end{array}$ \\
\hline Lakin & $\begin{array}{l}\text { Barley } \\
\text { Winter }\end{array}$ & (rar.) & 20 & 4 & $\begin{array}{l}\text { Pidor, Scottish Pearl, } \\
\text { Alaska }\end{array}$ \\
\hline Lakin & $\begin{array}{l}\text { Barley } \\
\text { Winter }\end{array}$ & (sel.) & 7 & 1 & $\begin{array}{l}\text { I-34-127, I-35-274, } \\
\text { I-35-33 }\end{array}$ \\
\hline Kearneysville & $\begin{array}{l}\text { Barley } \\
\text { Winter }\end{array}$ & (var.) & 19 & 5 & $\begin{array}{l}\text { Pidor, Tenn. Winter, } \\
\text { Wisc. Winter }\end{array}$ \\
\hline Kearneysville & $\begin{array}{l}\text { Barley } \\
\text { Winter }\end{array}$ & (sel.) & 7 & 1 & $\begin{array}{l}\text { I-35-142, I-35-274. } \\
\text { T-34-33 }\end{array}$ \\
\hline Morgantown & $\begin{array}{l}\text { Wheat } \\
\text { Winter }\end{array}$ & & 22 & 2 & Fulhio, T47-55, Thorne \\
\hline Arthurdale & $\begin{array}{l}\text { Wheat } \\
\text { Winter }\end{array}$ & & 10 & 2 & $\begin{array}{l}\text { Thorne, Canawa, } \\
\text { Nittany }\end{array}$ \\
\hline Kearneysville & $\begin{array}{l}\text { Wheat } \\
\text { Winter }\end{array}$ & & 14 & 2 & $\begin{array}{l}\text { Mammoth Red, Nittany, } \\
\text { Leapland }\end{array}$ \\
\hline Lakin & Wheat & & 14 & 2 & $\begin{array}{l}\text { Canawa, Trumbull, } \\
\text { Forward }\end{array}$ \\
\hline Morgantown & Oats & & 16 & 4 & $8+\mathrm{A}-32,90 \mathrm{~A}-27, \mathrm{I}-30-106$ \\
\hline Arthurdale & Oats & & 18 & 2 & $\begin{array}{l}\text { Japan Selection, Silver- } \\
\text { mine, } 78 \mathrm{~A}-32\end{array}$ \\
\hline Terra Alta & Oats & & 19 & 5 & $\begin{array}{l}\text { 84A-32, Japan Selection, } \\
\text { Silvermine }\end{array}$ \\
\hline Brandonville & $\begin{array}{l}\text { Oats } \\
\text { Soy- }\end{array}$ & & 20 & 5 & $\begin{array}{l}\text { 84A-32, Japan Selection, } \\
\text { Iowar }\end{array}$ \\
\hline Morgantown & $\begin{array}{l}\text { beans } \\
\text { Soy- }\end{array}$ & (grain) & 24 & 8 & Scioto, I-31-135, Wilson \\
\hline Morgantown & $\begin{array}{l}\text { beans } \\
\text { Soy- }\end{array}$ & (hay) & 24 & 8 & I-31-S7, Peking, I-31-135 \\
\hline Lakin & $\begin{array}{l}\text { beans } \\
\text { Soy- }\end{array}$ & (grain) & 16 & 2 & Kingwa, I-31-12, I-31-93 \\
\hline Lakin & beans & (hay) & 16 & 2 & I-31-88, I-31-114, I-31-135 \\
\hline
\end{tabular}

\section{Growers Are Taking to Hybrid Corn}

Five years ago, the Experiment Station began extensive research on hybrid corn. During this period the Station has carried on field trials in numerous counties in cooperation with the Agricultural Extension Division and with the growers themselves.

The results of these trials have demonstrated that from 15 to 20 percent more corn may be had by growing adapted hybrids than ordinary local varieties. Besides, considerably less blowing down may he expected in the hybrids. 
This checks with experience elsewhere. One state reports increases in yield from one-sixth to one-third resulting from using hybrid seed, and a large percentage of the growers have become "hybrid-conscious."

In West Virginia, E. J. Wellhausen and J. L. Cartledge have divided the state into four regions according to elevation and latitude. And they have set up a table for nearly every county, showing which hybrids they recommend for early planting under different conditions of soil. It is really a useful table that can be applied to nearly every farm in West Virginia. You can get this by writing to us for Mimengraph Circular No. 40, "Results of hybrid corn yield trials in West Virginia for 1939."

\section{Organic Matter Counts in Crop Rotation}

Fifteen years of research with crop rotations have shown us some definite results that we can now pass on to you. First let me say that in those rotations in which crop yields have been maintained or even bettered, year after year, there is as much or more organic matter than at the beginning of the experiment. On the other hand, where "poor" rotations were used, both the field of crop and the organic content of the soil have suffered. I think the following table brings this out clearly:

\begin{tabular}{|c|c|c|}
\hline Rotation & $\begin{array}{c}\text { Ave. Yield of } \\
\text { Corn } \\
1925-1926\end{array}$ & $\begin{array}{l}\text { Organic Matter } \\
\text { (Gain or Loss) }\end{array}$ \\
\hline $\begin{array}{l}\text { Corn (continuous) } \\
\text { Corn-Soybeans } \\
\text { Corn-Soybeans (Rye \& vetch) } \\
\text { Corn-Soybeans (Manured) } \\
\text { Corn-Oats-Clover } \\
\text { Corn-Oats-Clover (Manured) } \\
\text { Corn-Soybeans-Wheat-Clover } \\
\quad \text { (Manured) }\end{array}$ & $\begin{array}{l}\text { Bushels } \\
37.7 \\
43.1 \\
55.9 \\
65.8 \\
64.8 \\
69.7\end{array}$ & $\begin{array}{l}\text { Percent } \\
-18 \\
-23 \\
-12 \\
+11 \\
+1 \\
+10\end{array}$ \\
\hline
\end{tabular}

It should be added that manure and sod crops have both been most helpful in maintaining and building up that organic matter. And we have good indications that both nitrogen and potash help to boost the yields in most of the rotations. Potatoes have shown a marked response to potash, on both limed and unlimed plots, to the tune of a 23.9 bushel increase on unlimed, and 37.4 bushels increase on limed plots. On most other crops, too, we got better results where lime was used along with fertilizer. T. C. McIlvaine and G. G. Pohlman have charge of this experiment at Lakin.

I am going to cite another table (it's a short one) to show you the 
value of lime, and organic matter in increasing the yield of corn in a corn-and-wheat rotation in 1939.

\section{Cover Crop}

No cover crop

Sweet clover

Rye \& vetch

Clover \& timothy

$\begin{array}{cc}\text { Limed } & \begin{array}{c}\text { Unlimed } \\ \text { (Bushels }\end{array} \\ 26.5 & \text { Acre) } \\ 104.2 & 18.0 \\ 82.5 & 49.0^{*} \\ 88.6 & 34.7 \\ & 47.2\end{array}$

\section{Crop Responses to Different Fertilizers}

At Arthurdale, the yields of corn in a corn-soybean rotation showed definite response to potash. The highest yield was obtained on a plot that got 500 pounds per acre of a $4-12-4$ fertilizer. The yield on this plot was 10.7 bushels more corn than on the untreated plot.

At Lakin, in a corn--wheat-clover rotation, we got corn yields running from 56.8 bushels per acre on unfertilized plots to 93.2 bushels on plots receiving 10 tons of manure plus 125 pounds of 20 percent superphosphate.

In a corn-soybean-wheat-clover rotation, wheat yields were increased from 9.5 bushels per acre on the untreated plot to 19.0 bushels where 250 pounds of a 4-12-4 fertilizer was applied. It's the phosphate and potash that seemed to be lacking in the rotation, and the complete fertilizer supplied that deficiency.

Organic matter is what counts. As I reported under crop rotations, the longer rotations with clover will maintain the supply. But if short rotations must be used, the corn yield can almost be doubled if sweet clover is plowed under. T. C. McIlvaine and G. G. Pohlman found this true even when large quantities of fertilizer were used.

\section{FRUIT AND VEGETABLE CROPS}

\section{Sod Helps Elberta Withstand Winter Temperatures}

You remember what a prolonged winter we had a year ago, in 193940. Not much chance for damage from freezing and thawing. Just the reverse from the mild winter of 1938-39.

It seems that some peach varieties will withstand the coldest weather, but will lose their buds in a changeable winter. With other varieties the reverse is true. And a few seem to withstand both conditions fairly well.

In that hard winter last year, under clean cultivation plus cover

\footnotetext{
* Here we used vetch for a cover crop instead of sweet clover. All plots received 250 pounds of 4-12-4 fertilizer, appljed in the hill. The cover crops were plowed under before the corn crop.
} 
erops, the varieties with least bud kill were Carman, Golden Jubilee, Greensboro, Hiley, Raritan, Rose, Red Bird, Hale Haven, and Rochester. R. S. Marsh and W. H. Duis report that at the other end of bud mortality were Eclipse, Oriole, Polly, and Primrose.

Normally Elberta is in this latter class, but when growing in sod ( $10 \%$ bud kill), this variety was just as hardy as Rochester, Carman, and Greensboro, where these were grown under clean cultivation.

\section{Variety Tests of Small Fruits}

If you are interested in having fresh berries for the table in September and October, the Indian Summer everbearing red raspberry will be of interest to you. It lacks the quality of some of the spring-bearing varieties but we think it is distinctly superior to anything of this type that we have seen in the past. We still feel that the place for ever-bearing strawberries and raspberries in West Virginia is in the home garden as a general rule.

W. H. Childs and R. S. Marsh have also had an opportunity to observe the Taylor and Marcy red raspberries in West Virginia, and they seem to be promising. Both are large, firm berries, of high quality, and promise to yield well under our conditions.

\section{Cultural Treatments and Fertilizers for Fruits}

Have you wished you could keep your raspberries cleaner during the picking season? W. H. Childs has found that keeping the ground covered between the plants with enough mulch to smother out weeds not only results in cleaner berries but also stops erosion and gives larger yields than when cultivation is practiced. Don't neglect a fairly liberal application (200-300 pounds per acre) of a nitrogen carrier, however, when using mulch.

\section{Blueberries}

For the third consecutive summer, W. H. Duis has made plant selections from the principal native blueberry areas of the state. We now have over one hundred selections of superior types. These will be used in propagation and breeding experiments.

Trial plantings of high-bush named varieties have been made in four counties. Propagation experiments are completed on the high-bush types, and satisfactory recommendations can be made. Crossings of high-bush forms with native selections have been attempted during the past two seasons of bloom. Seed dormancy and treatment with colchicine studies are in progress. In one isolated case a blueberry bloom was produced nine months after the seed was planted. 


\section{Climate and Soils in Fruit Production}

The Department of Horticulture in cooperation with the Soil Conservation Service has completed a two-year study of certain properties of soils in 20 commercial orchards of the Eastern Panhandle. Each of these was selected as representing different cultural practices and types of vegetative cover for the Hagerstown, Frankstown, Frederick, Lehew, Dekalb, and Berks soil series. Many of the technical observations made by R. H. Sudds are too involved to be described and explained here. Perhaps the chief lesson from the study is the importance of protecting the soil surface with a close-growing, more or less permanent type of cover, with an adequate mulch of organic material.

Either of these methods maintains desirable conditions in the soil, and both of them are effective means of conserving soil and water, which have an important influence upon profitable orcharding in the Eastern Panhandle of West Virginia. The paint and varnish slogan, "Save the surface and you save all," applies even more accurately to our soils.

A second important lesson is that certain shallow soils should be used either cautiously or not at all for commercial fruit growing, because at best they cannot hold enough available moisture for efficient fruit production year after year.

\section{Not All Rootstock Combinations Will Work Out}

Perhaps the most important contribution so far of the research in fruit-tree rootstocks, conducted cooperatively between the Department of Horticulture and the United States Department of Agriculture, has been an appreciation of what not to recommend to the fruit grower. We have reduced or largely eliminated expensive experimenting with rootstocks on the part of individual orchardists. We know much better than we did a few years ago that certain scion varieties of fruit should not be budded or grafted on a number of different rootstocks of the apple and the sour cherry. We still do not know what patricular combinations of scion and rootstock will make a medium-sized, long-lived apple tree.

A severe, tornado-like storm struck the University Experiment Farm at Kearneysville, where most of our rootstock research is conducted by R. H. Sudds. The results of this storm showed us beyond any doubt that certain combinations of scion and rootstock couldn't take it when the big winds came. It is much better that a single agency like the Experiment Station should lose its trees in this way if we can save the fruit grower similar losses from his own experimenting. 


\section{Sooty Apples}

Apple orchards in the industrial bottomlands of the Northern Panhandle are saddled with soot from the mills, factories, and brickyards. There is no solution to this problem except mechanical removal after harvest. In D. S. Brown's experience the most effective way is to use a 10 percent "BW" silicate solution at $80^{\circ}$ Fahrenheit in an underbrush, flood-type appie washer and after that, a "two-way" cleaner. This treatment takes care of spray residue at the same time.

\section{There Are Reasons for Pruning Cherry Trees}

Pruning cherry trees is a standard practice, and not without good reason. R. H. Sudds and R. S. Marsh experimented with different degrees of pruning Montmorency trees grown on both Mazzard and Mahaleb stocks. They were hardly surprised to find that sparing the knife gave substantially heavier yields in all cases.

But here's the hitch: the grade of fruit from unpruned and lightlypruned trees on both rootstocks was inferior in size to the cherries from moderately and heavily-pruned trees. And the ripening was more uneven with the unpruned and lightly-pruned trees. Again, this halfhearted practice can result in faulty secondary framework. And if you ask the pickers, they'll take their trees pruned, every time.

\section{Increasing the Color of Apples on the Twig}

At last our chemists can tell the story of improving the color of growing apples!

It has taken years of study and experiment, but the method followed is fairly simple. First the nature of the coloring matter in the applc skin had to be determined. That was a painstaking piece of work because it took so much apple skin to extract a little of the color. Then what little residue was there, had to be analyzed for chemical content.

The next step was to look for a spray material that would promote the formation of this chemical. Not until then was it possible to go to the field and spray for better color on the developing fruit.

By hand and by power, no less than 50 trees were sprayed with dilute solutions of sodium thiocyanate. On each tree a single limb was used as a control limb and covered with heavy canvas during the spraying operation. The trees were in full bearing and were sprayed from one to four times in July and August. Varieties included Stayman, Rome, York, Delicious, Grimes, Golden Delicious, Wagner, Duchess, Maiden Blush, and Wealthy. These trials were carried on at Kearneysville and Morgantown. 
The results were very gratifying to the experimenters, R. B. Dustman and I. J. Duncan, because, when the fruits were picked, in almost every case they found an increase in the amount of red pigment formed, and also a tendency toward less of the dark-green ground color and more of the lighter greens and yellows that show up in more mature fruit.

This experience enables us to say that we have made considerable progress in putting red or yellow color on apples, but the experiment isn't over yet. The spray causes some foliage burn which may or may not be excessive. It will take a few seasons to tell whether this foliage injury is a serious matter and whether it can be avoided.

\section{Variety and Strain Studies of Vegetables}

Yellow sweet corn, 28 varieties and strains; canning tomatoes, 12; canning peas, 21 ; potatoes, 114 : that is the number we have been putting through the works lately, at different altitudes, to see what are best for West Virginia conditions where the crops can be grown. Results are too numerous to mention here, so if you want the information, write to the Department of Horticulture for a copy of Mimeograph Circular No. 33. More recently between 400 and 500 potato varieties and strains have been under observation, and K. C. Westover and E. P. Brasher report that some of these are very promising. This work is in cooperation with the United States Department of Agriculture.

\section{Potatoes Respond to Complete Fertilizer}

This Station has experimented with fertilizers on potatoes for some years, and we are able to report that a complete fertilizer (NPK) applicd in the seed drill is probably necessary under all conditions. There seems to be little evidence that the more common minor elements are of much import to us. More potassium, particularly on the soils of good tilth, has greatly increased the yields of a salable crop. Applications of 1000 to 1400 pounds of a 5-10-10 standard fertilizer mixture are suggested.

Experiments by K. C. Westover with short rotations for early-crop potatoes indicate that a potato-soybean hay-rye-and-vetch rotation has given the greatest yields, provided an application of at least 800 pounds of a good potato fertilizer is used. Whether the soybeans should be turned under will depend largely on what potatoes or soybean hay will bring on the market.

\section{When to Apply Potato Fertilizer?}

For two years E. P. Brasher has been experimenting at the Arthurdale Experiment Farm and at the Lakin Experiment Farm to determine 
the advisability of applying split applications (part at one time, part later) of complete fertilizer to the potato crops. From these experiments it was evident that the longer the fertilizer application was delayed after planting, within the limits of our experiments, the lower the yield.

\section{Starter Solutions with Tomatoes}

A starter solution composed of 4.25 pounds of a $5-10-10$ fertilizer mixture in 50 gallons of water proved beneficial in growing tomatoes and peppers. When E. P. Brasher used this solution at the rate of one pint per plant at setting time, both the early and the total yields were increased.

\section{Two Versus One Tomato Plant per Stake}

In an experiment this past season E. P. Brasher compared the results of tomato plants set in those two ways. The yield per acre of early marketable tomatoes-when the price is good-was 17,869 pounds for the twin plants, or 38 percent better than the 12,965 pounds for the single plants. In the total marketable yield for the season the twin plants produced 31,166 pounds and the single plants only 21,360 pounds. The difference is 46 percent. Here is a substantial increase in favor of double planting. The additional cost in plants and labor amounted to only 20 percent more than the usual system of planting tomatoes.

\section{Waxing Cabbage Plants}

Mr. Brasher also used various dilutions of Brytene Emulsion No. 333-B to see if this material would aid cabbage plants in withstanding the shock of transplanting. Evidently most of the dilutions did not, since the wax caused a slowing up of plant growth, and this resulted in lower early and total yields.

\section{Does it Pay to Harden Vegetable Plants?}

At Arthurdale, in Preston County, E. P. Brasher has been experimenting with vegetable plants to determine the yield from hardened and from tender plants and the ability of these plants to withstand low temperatures and strong, cool winds very early in the season.

As for tomatoes, we obtained much better yields, both early and total, from tender and slightly hardened plants than we did from plants that were severely hardened. In fact we are convinced that the hardening of tomato plants decreases the yield in proportion to the severity of the hardening treatment, and it does not make the plant better able to survive under early spring conditions.

With peppers it is a different story. Here the plants slightly and 
moderately hardened produced larger early yields and larger total yields of fruit than the tender or unhardened plants. We could not see any difference in the ability of the hardened and tender plants to withstand unfavorable weather conditions.

When we tested cabbage and head lettuce plants, the hardened plants withstood lower temperature and produced better yields than the tender plants.

\section{Rye $\mathcal{E}$. Vetch for Green Manures}

What are the most practical rotations for the production of early cabbage and tomatoes? We have been working on them for ten years. The rotations vary in length from the continuous growing of these crops on the same land every year, together with green manure crops, to threeyear rotations in which hay and other green-manuring crops have been included for varying periods of time.

K. C. Westover reports that rye \& vetch turned under after tomatoes each year has consistently yielded higher than any of the other crops used. In the two and three-year cropping systems, timothy \& clover in the rotations has resulted in slightly higher yields than either sweet clover or alfalfa. None of the longer rotations appears to be better than the continuous cropping of tomatoes together with the use of rye $\&$ vetch for green manures.

In the early cabbage rotations, cabbage every year by rye \& vetch has given the best yields of any of the crops used. In the two-year rotation, the use of soybeans and rye \& vetch for manurial purposes was best. The yields from the three-year rotations were somewhat greater but not enough so to justify the extra expense of maintaining the longer rotation system.

\section{ANIMAL HUSBANDRY}

\section{Pastures for Finishing Yearling Steers and Heifers}

Since 1930, 70 high-grade Hereford cows, bred each year to registered Hereford bulls, have been maintained at Lewisburg for the production of beef calves. The calves are born around April 1 and run with their dams on pasture until about November 10, when they are weaned and started on feed. Around December 1 the calves are placed in winter quarters and fed a ration of corn silage, clover (or alfalfa) hay, cottonseed meal, and coarsely-ground shelled corn for 140 days or until about May 1. So C. V. Wilson tells me. He and W. H. Black of the Federal Bureau of Animal Industry have been working on this cooperative project. 
The heifers and the steers are fed separately but on the same ratiun. The amount fed is in proportion to the average weight of the steers and of the heifers.

At the end of the winter period of 1939-40, the heifers had been fed 340 pounds of corn and 70 pounds of cottonseed meal each in addition to the corn silage and hay. The steers were heavier than the heifers and had received 440 pounds of corn and 70 pounds of cottonseed meal each.

From May 1 to August 2 the steers ate 780 pounds of corn and the heifers 680 pounds each. Some 1220 pounds of ground shelled corn and 70 pounds of cottonseed meal in the case of the steers, and 1020 pounds of corn and 70 pounds of cottonseed meal for the heifers, along with pasture and silage and hay, in 16 months had produced 915-pound steers and 780-pound heifers. Twelve of the top heifers had been kept for herd replacements. The top heifers were above the average in weight; this widened the difference in the average weights of the steers and heifers.

In 1940 the heifers were divided into two lots during the pasture season. One lot was fed corn and alfalfa hay in the barn and the other an equal amount of corn in addition to pasture. The amount of hay fed was adjusted so that each lot of heifers made the same gain. It took 10 pounds of alfalia hay per head daily to equal the gains made by the lot on pasture.

The gains made by both heifels and steers; the relatively small amount of grain necessary to make finished beef; the quality of the meat as measured by its carcass grade of from good to choice and by its ready acceptance by the meat trade and by the consumer-all go to show that a maximum of grass and home-grown roughage may be marketed satisfactorily and profitably under this plan. Talues of $\$ 40$ to $\$ 50$ were realized for the heifer and steer calves used. This plan of beef making in West Virginia is designed to do two things:

(1) Permit the maximum use of the state's extensive pasture land, and

(2) Require a minimum use of its limited area of tillable land.

\section{First-Cross Corriedale Ewe for Wool and Mutton}

This experiment goes back 11 years, when 120 native grade Hampshire-type lambs with a known history of breeding were born. In the fall of 1930 these were divided into 4 lots of 30 head each and were bred to 4 rams of the Corriedale breed. The ewe lambs from these matings were all kept for breeding back to Corriedale rams. The wether lambs were sent to the Federal research station at Beltsville, Maryland, for slaughter and for meats investigations. 
Breeding the ewe offspring back to Corriedales has continued until the fourth generation of such ewes has been produced. That is as far as we are going with our investigation.

Two years ago I reported that there was a marked improvement in the length of staple and in the grease weight of the fleece of the daughters in comparison with their Hampshire-type dams. This obser. vation has been well sustained in the third and fourth-cross ewes. At the same time, they are more uniform in markings, in body conformation, and in fleece characteristics than the first-cross ewes.

A Corriedale ewe of this type (that is, first-cross) is of a satisfactory size with a wonderful fleece. When mated to a down(mutton) breed she will produce an excellent market lamb.

From the standpoint of market lambs, the first-cross wether lambs have shown themselves greatly superior to succeeding generations. The second, third, and fourth-generation wethers sired by Corriedales have tended toward lighter weight at a given age, toward slower maturity, and toward less well finished carcasses.

This is a cooperative project between the West Virginia Station and the Bureau of Animal Industry, United States Department of Agriculture. C. V. Wilson is in charge for West Virginia, and D. A. Spence: for Washington.

\section{Leave the Ears in Your Silage}

There is something very pleasant about the smell of well-cured ensilage as you take it from the silo to feed your stock. That brings up the question, What part of the corn plant is doing the most good? By this time we have a few observations to report.

In 1938 E. A. Ijivesay and A. H. VanLandingham experimented with Boone County White corn in feeding two lots of steers. One lot had whole silage for the first 70 days, then ear silage for 56 days. The other lot received stover silage throughout the whole period of 126 days. Well, the first lot gained 172 pounds on the average for each steer, and the stover lot only 95 pounds. The remarkable thing about it is that when the first lot had ear silage and averaged 87 pounds gain, the other lot almost stood still and showed only 14 pounds gain on their continued stover ration.

We had similar results last year, when we used Reid's Yellow Dent on two lots of beef cows. For the first 56 days we fed Lot I normal silage and Lot II stover silage along with mixed hay and cottonseed meal. Then for the last 12 days, the Lot I took ear silage, the other lot stover silage. The average gain for Lot I was 140 pounds in 98 days, against only 49 pounds for Lot II. 
These results compare favorably with the results with steers. The dry matter of normal silage gave slightly better gains than the dry matter of stover silage, and ear silage made for very much larger gains than stover silage.

On the basis of the 1938-39 studies (Boone County White corn), where digestion trials were run, 34 percent of the green weight, 46 percent of the dry matter, and 53 percent of the total digestible nutrients of the corn plant were contained in the ear.

\section{Left and Right May Not Be the Same}

You wouldn't believe, would you, that the bones from the left and right sides of a hog were not identical in composition? Well, the question had us stumped until we put it to the test. Our chemists looked into the composition of different parts of the skeletons of white rats, chicks, pigs, and dairy heifers. For many years, scientists have assumed that the bones from the two sides of animals were identical in make-up or other properties. Research by C. E. Weakley, Jr., and R. B. Dustman proved that this is not necessarily the case, at least as far as chickens and hogs are concerned. Here we found a tendency for the left side to have heavier bones with a higher moisture content.

Such knowledge is important because a great deal of research in animal and human nutrition is being carried on by many agencies throughout the country, and in nutrition research, much, sometimes everything, depends on the chemical analysis of bones.

\section{What Protein for Your Battery Chick Ration?}

Fish meal, meat scraps, soybean oilmeal, corn gluten meal. Which of these would you use to supplement your chick ration? T. B. Clark, A. H. VanLandingham, and T. D. Runnels have experimented with numerous lots of White Leghorn chicks, 22 to the lot, and they find that satisfactory results are had when either soybean oilmeal or corn gluten meal are supplemented with fish meal. On such concentrate mixtures, growth was equal to results when fish meal was used alone. Corn gluten meal alone is not satisfactory unless fish meal is added. Even in combination with meat scraps, corn gluten meal is still inferior to soybean oilmeal. Alone or in combination, the latter is superior to corn gluten in any combination.

In these trials we used a starting ration that contained wheat byproducts. When we replaced the wheat with cornmeal, slower growth resulted. Then soybean oilmeal plus fish meal proved to be the only efficient combination tested. Corn gluten meal with meat scraps barely 


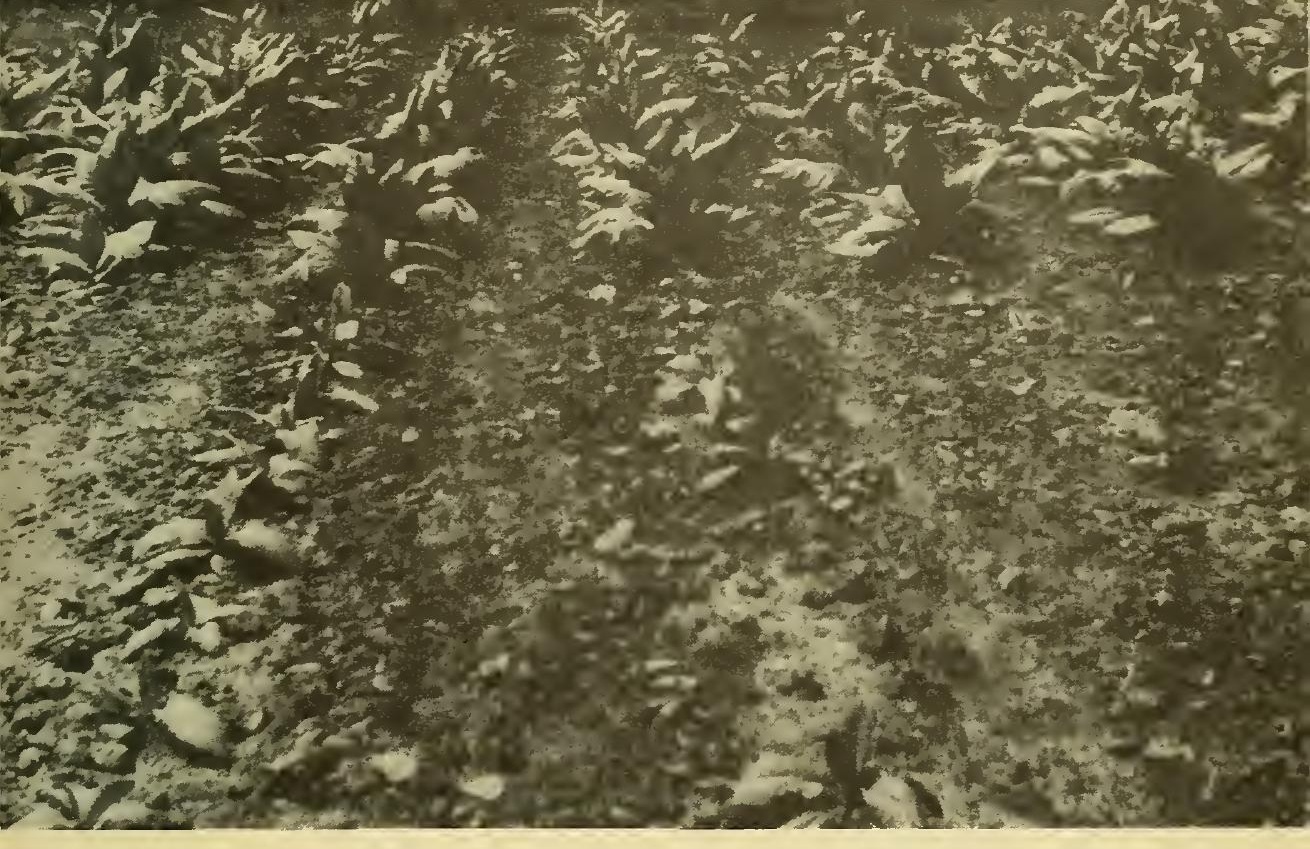

Resistant and susceptible strains of tobacco grown on soil infested with rootrot. A resistant strain from Kentucky is in background, and Improved Kelley (susceptible) in foreground.

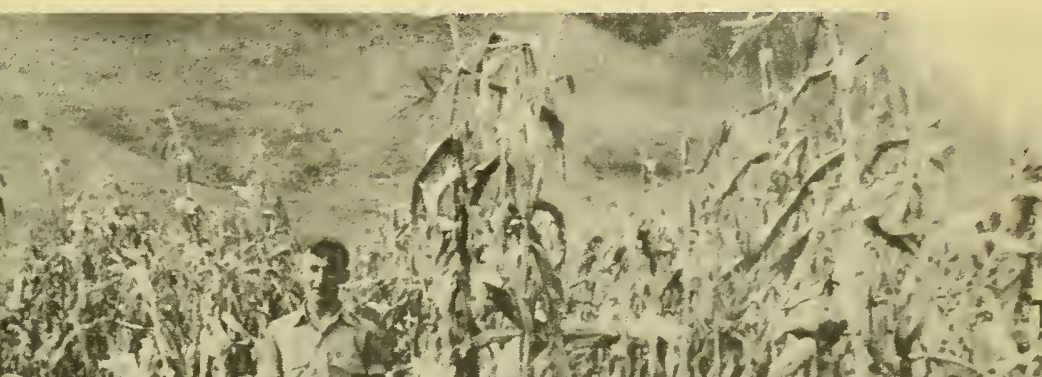

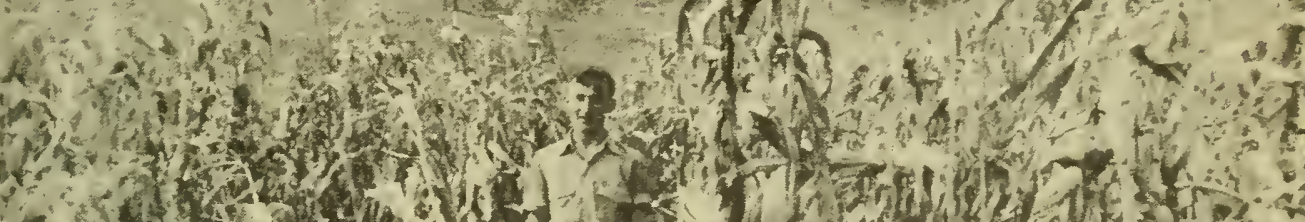

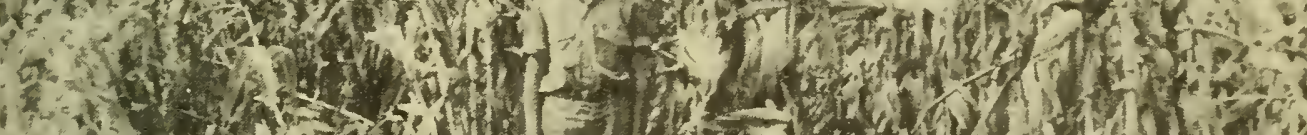
*

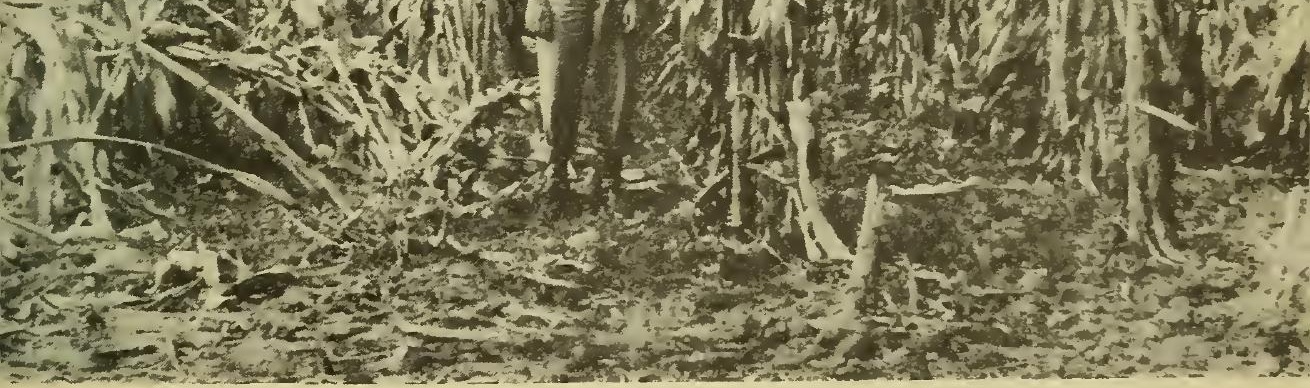

Differences in standing ability between hybrids and ordinary varieties. In the hybrid (U. S. 44) on the right, all plants remained standing after a severe storm. Nearly all of the ordinary variety on left blew down. 


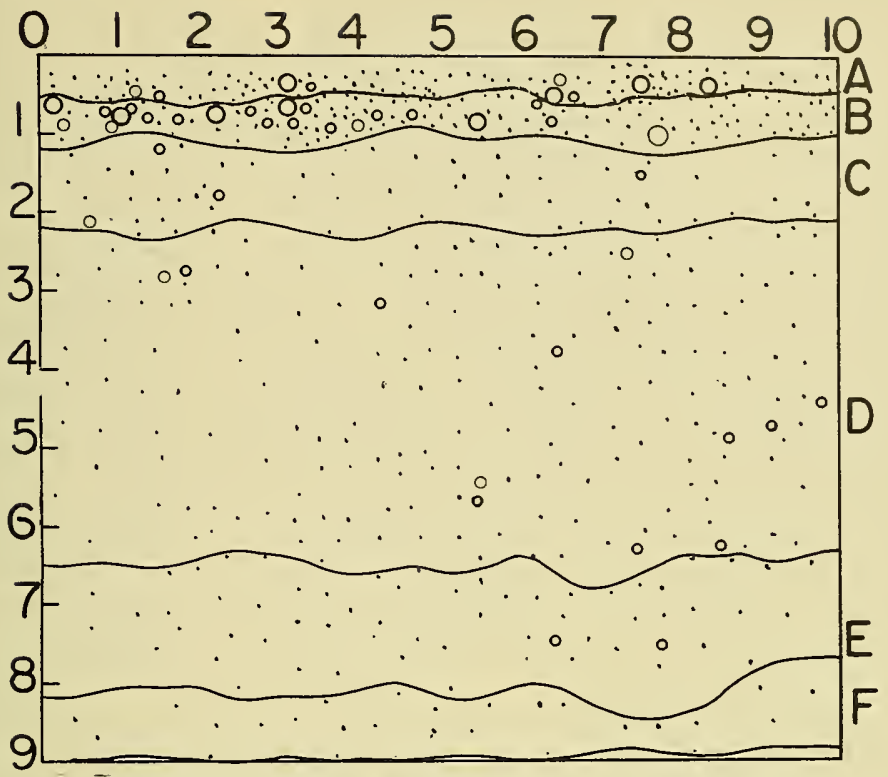

Would you rather set fruit trees on this soil?

\section{FEET}

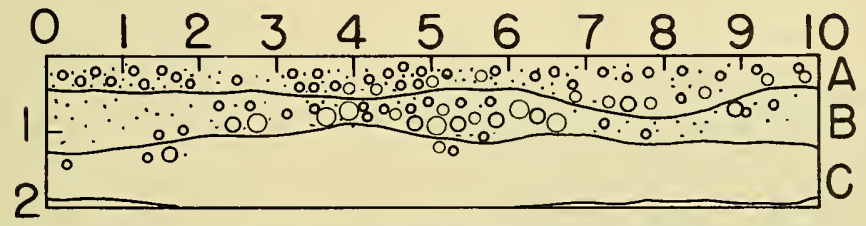

Or on this soil? Circles and dots indicate the depth of rooting of apple trees. The letters A, B, C, etc., indicate soil "layers."

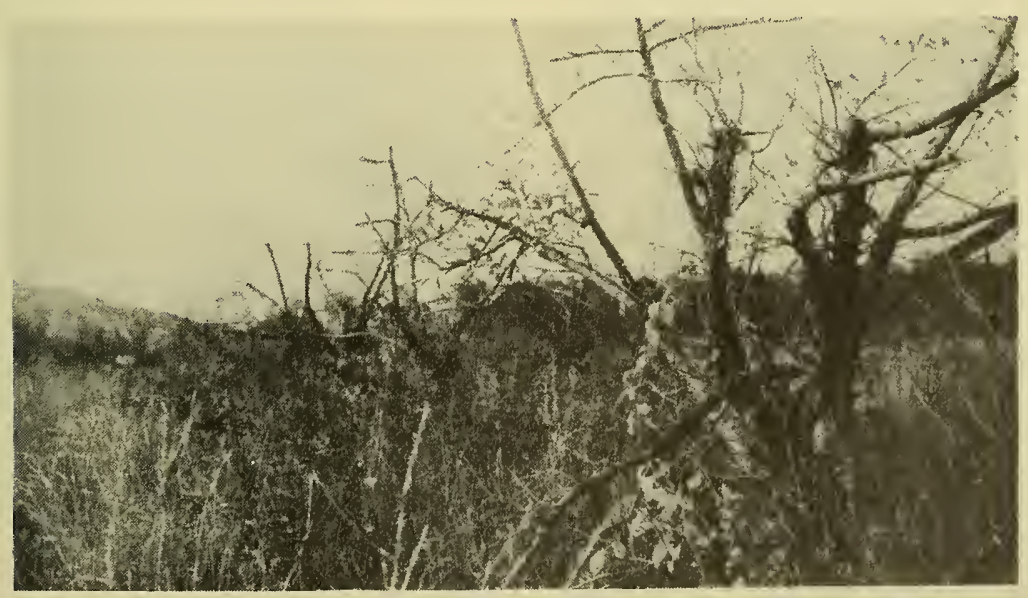

Fruit trees planted on shallow soils of low moisture-holding capacity may look like this after a severe summer drought. 


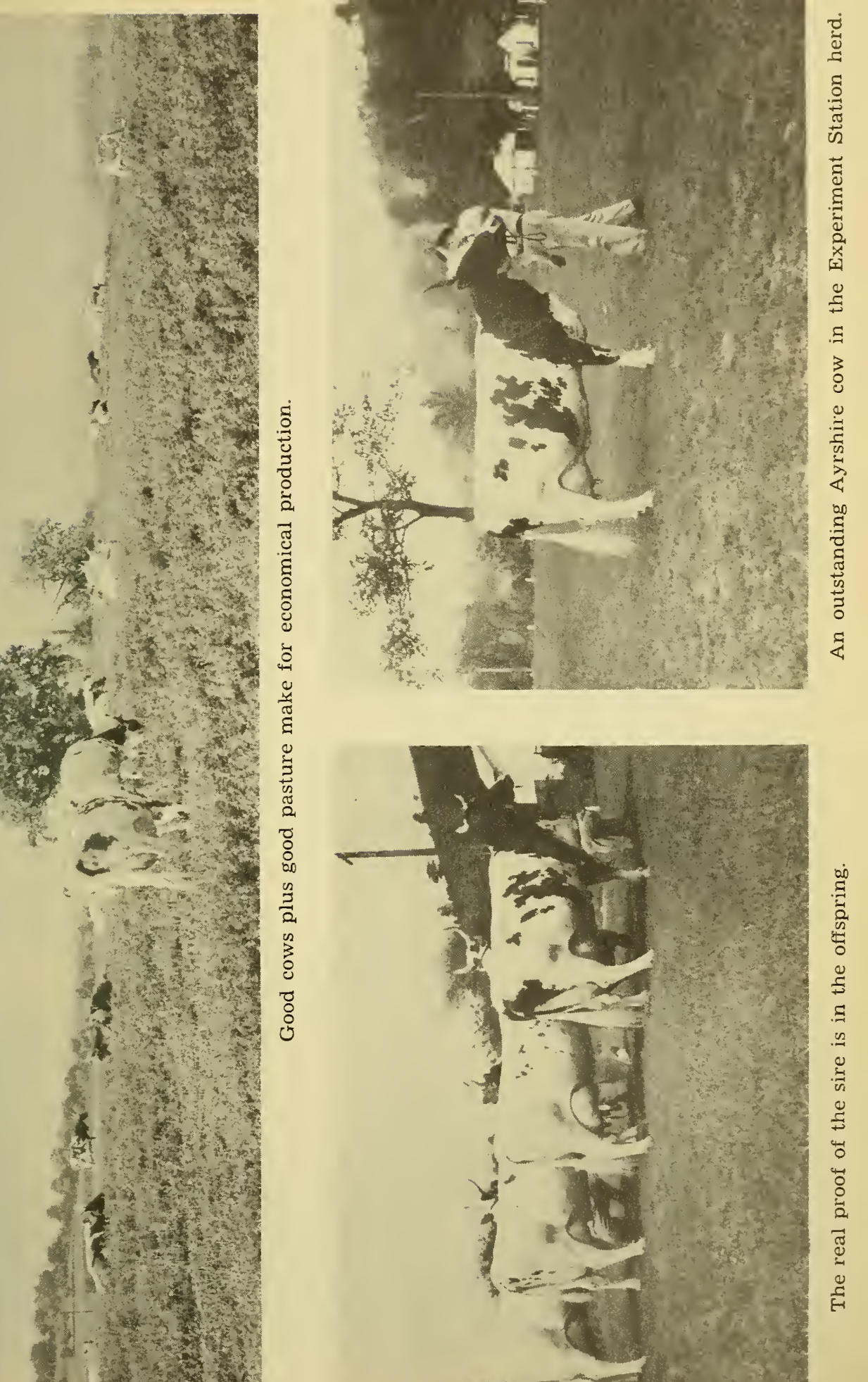




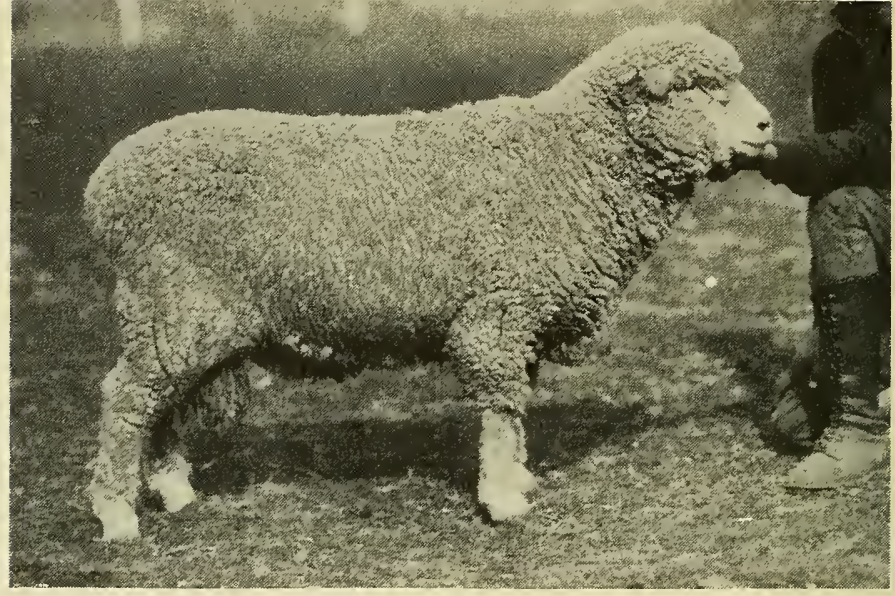

A Corriedale ram.

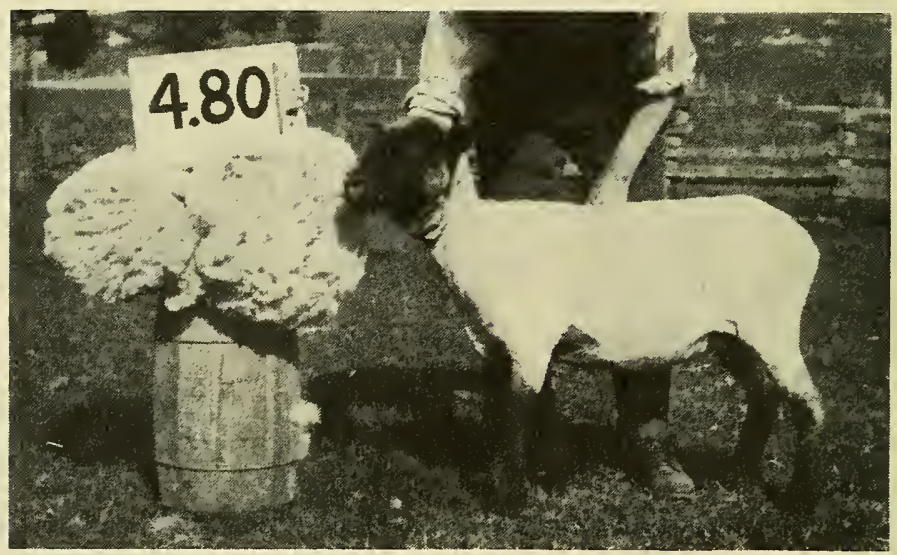

A typical grade Hampshire-type ewe.

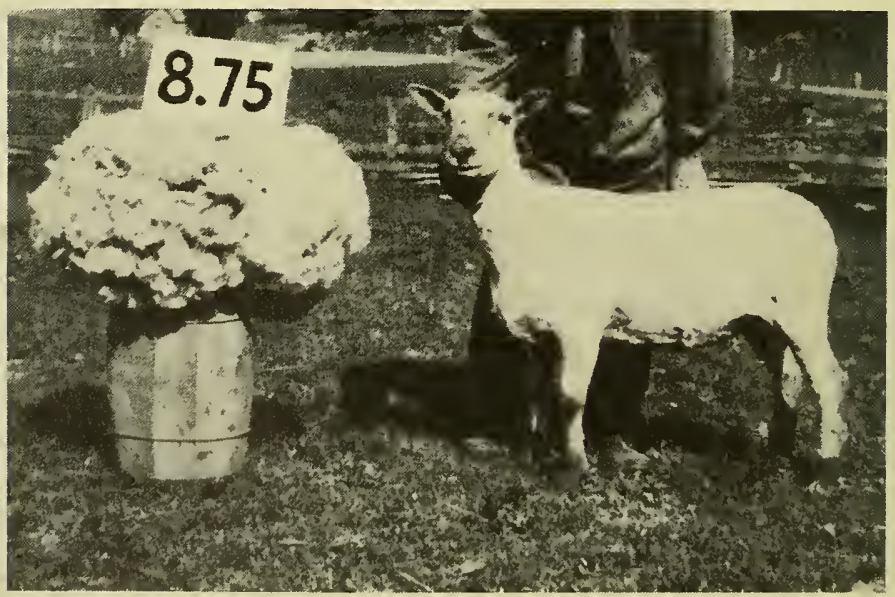

A daughter of this Hampshire-type ewe and by a Corriedale ram. 


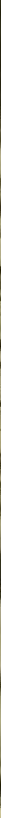

This land has been neglected and its productivè capacity largely destroyed.

An organization has been developed on an experimental basis with the purpose to furnish, on an economic basis, skilled management of timberland to any citizen of West Virginia.

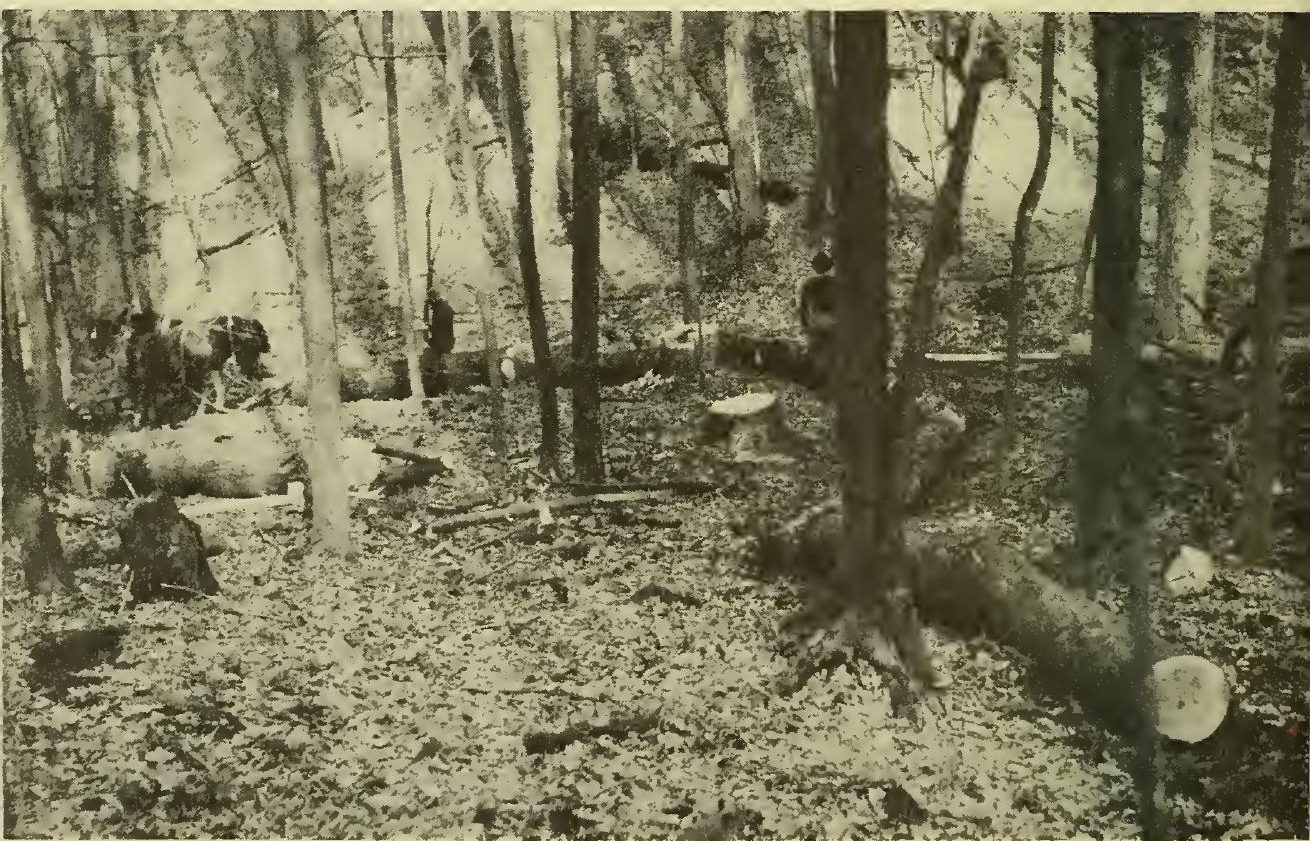

This land has been managed skillfully to produce a crop of the highest value in terms of dollars per acre per year. 
supported growth. However, the corn gluten meal increased the deposition of yellow pigment in the shanks, and that is important in broilers.

The following table shows the make-up of eight of the twelve rations used in this experiment.

Rations and Mean Body Weight

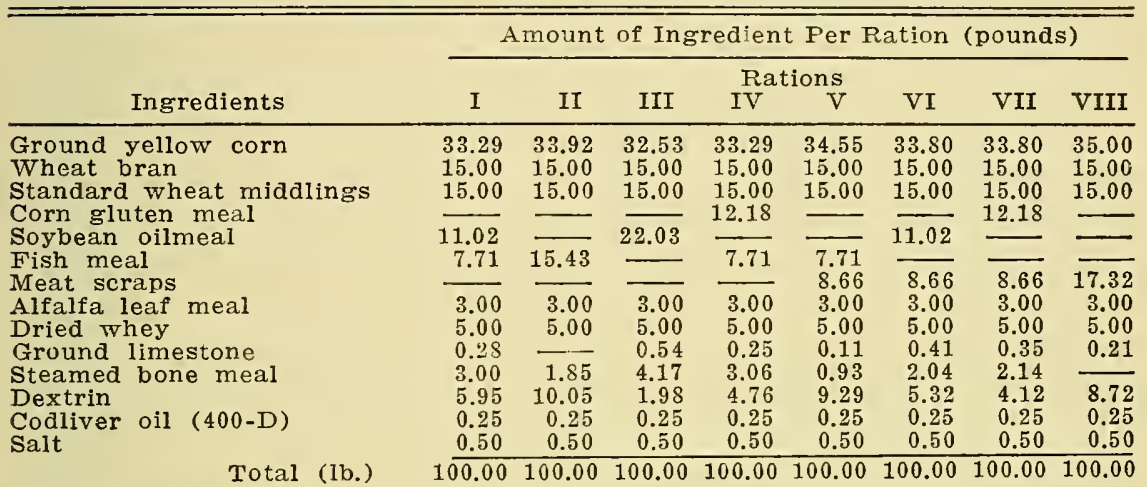

Mean body weight of males and

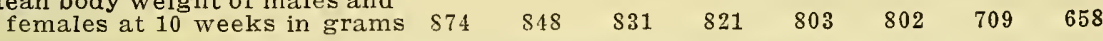

\section{Effect of Rations and Method of Feeding Grain on Egg Production}

In recent years, E. T. Wightman has used several lots of S. C. White Leghorn pullets to compare the effect of different amounts of oats in the ration. The lots were all confined to the laying pens during the trials.

Two lots were fed an all-mash ration that differed only in the amounts of ground oats and cornmeal. One lot received a mash containing 23 percent cornmeal and 40 percent ground oats. In the other lot these proportions were reversed. The high-corn lot consumed a little less feed, laid more eggs, and required less feed per dozen eggs, but mortality was slightly higher.

Other lots received varying amounts of ground oats or whole yellow corn as well as alfalfa leafmeal as part of the mash. The results are not complete, but so far we have noted no consistent difference between mashes containing 10 percent and 20 percent ground oats or the addition of whole oats fed in hoppers, free choice, when measured by percentage production and by the amount of feed required per dozen eggs.

\section{High or Low Protein Rations for White Leghorns?}

For some time this Station has been concerned with the question whether much or little protein in the ration has anything to do with 
early death or with egg-laying ability in White Leghorns. To carry out the proper research for this study, it took three sorts of experimenters - the poultryman, the chemist, and the reterinarian. That included T. B. Clark, C. E. Weakley, Jr., and J. H. Rietz. After a few years they can point to these results:

Six lots of pullets, 300 at the start, completed the first laying year in October, 1939. Four of these lots were reared in confinement and two on range from $S$ to 22 weeks of age. Under both methods, the percentage of protein in their rations had much to do with performance. Birds that were begun on a low-protein ration (131/2\%) and that were continued on it in the laying period had the lowest production and a high mortality in comparison with the other lots. It made no difference whether these were reared on range or in confinement. Now, when that protein level was stepped up to 18 percent, we found lower mortality and higher production. Thus, pullets need an adequate supply of protein in the growing ration, although we did get satisfactory performance from slowly developed pullets by placing them on a high-protein ration when laying commenced.

This experiment will have to continue a few more seasons before we are ready to make recommendations. It may be well to remark at this point that in an earlier phase of this experiment we found that length of life is not affected by egg production during the first year. The high-producing birds lived as long as the low producers.

\section{Selecting Breeders for Long Life in Progeny}

Should farmers use older roosters on their hens if ther want production in old age? We'd like to know the answer too.

By way of experiment, E. T. Wightman and E. N. Moore banded 499 S. C. White Leghorn pullets in the fall of 1938 . These were the daughters of 10 males and 62 females. No culling was done, and each bird was carried at least long enough to complete a full 365-day period from the date of laving the first egg. If any of them got moribund, they were removed and killed for post mortem. All pullets were vaccinated for chicken pox while on range and were tested for pullorum disease at the time of housing, but no reactions were found.

Two-thirds of the lot lived to finish the year. Half of the remainder showed fowl paralysis.

The livability of the daughters of some of the males varied from one-third to better than two-thirds. Within certain families (the progeny of 1 male and 1 female), the livability of the daughters ran all the way from zero to 100 percent. 
When we inspected the pedigrees of the dams with high livability we found a batch of individuals that have lived and produced well for three to six years.

There is a possibility that by selecting older birds as breeders, alon! with testing the progeny for production, we can increase the livability of daughters. But we still have far to go before we can make recommendations.

\section{Crossbreeding Turkeys for Better Market Quality}

The results that we have had from crossbreeding in turkeys suggest to us that one might expect as good results from crossing two strains of one variety as from crossing two varieties. Improvement from crossbreeding apparently is due largely to chance.

T. B. Clark and E. A. Livesay have crossed the Bronze, Bourbon Red, and Black varieties. The 659 purebred and crossbred offspring from these varieties have been studied to note any changes from crossbreeding in growth rate, body conformation, and market grade. So far, crossing has not improved the toms. In the hens, the market grades of the crossbreds and Bourbon Reds were similar. Both were superior to to the Bronze. Of course, other strains of these varieties might give different results and we are studying different strains and methods of crossing.

Growing the turkeys in confincment increased the feed consumption as much as 17 percent as compared to growing them on a limited range.

\section{DAIRY HUSBANDRY}

\section{There Is No Pasture Like Bluegrass}

Bluegrass is still the best milk producer and body grower. Of course, it gets short in the hot, dry spells, and that is the reason for trying alfalfa and Korean lespedeza as pinchhitter's. At Wardensville $\mathrm{H}$. O. Henderson, R. A. Ackerman, and G. G. Pohlman have found no advantage in growing lespedeza, with its 45-day growing season. Heifers gained most by far (159 lb.) from bluegrass, and alfalfa was a distant runner-up with $87 \mathrm{lb}$. — not far ahead of lespedeza with a $72 \mathrm{lb}$. gain per animal.

\section{Fertilizer Gives Your Stock More Pasture Days}

When you put dairy heifers on pasture in spring, you expect then to add weight during the season. They will, if there is fertility in that pasture. 
At Wardensville we tried out that theory by putting stock on pastures that had had no fertilizer since 1933. The one exception to this was that the plots that had received complete fertilizer (N-P-K-L) before 1933, got a yearly supplement of nitrates.

H. O. Henderson and R. A. Ackerman report that as you step up the fertilizer treatment from nothing to phosphorus and lime, then to the same plus potash, and finally to nitrogen, phosphorus, potash, and lime, the total number of pasture days, and with it the total gain in weight of the animals, goes up. The average daily gain may not vary much between the animals grazing on the different plots, but what counts is the number of pasture days, or the carrying capacity. That's where fertilizer counts.

\section{Alfalfa as the Only Source of Protein in Dairy Rations}

We have learned that alfalfa (leaf meal and hay) as the only source of protein, plus energy-producing feeds like cornstarch, plus minerals like steamed bone meal, may be all right for growing dairy calves, but this ration is not satisfactory for animals in lactation. The system may crave fat, too. So G. A. Bowling and A. H. VanLandingham varied the diet for some experimental cows by substituting corn oil for part of the cornstarch or chipped corn sugar.

So far we can report that growth has been satisfactory from this revised diet, and all of the cows calving have dropped normal, healthy calves, and are producing milk. But we are not sure that this ration is adequate for economical, sustained milk production. We have to give it more time.

\section{Can Feed Have Any Bearing on Garget?}

No milker likes to run into gargety milk during his morning or evening chores. Yet mastitis is a condition that may be encountered in any dairy herd.

Our dairy husbandmen and disease specialists were curious to know whether the kind and the amount of feed had anything to do with the trouble. So they divided 27 Holstein cows into two lots and fed them different amounts of yellow corn meal, corn gluten feed, cottonseed meal, ground oats, salt, and bone meal, in different combinations. At regular intervals they made physical examinations of the udders and chemical tests of the milk for both experimental and control cows. They found wide differences in the severity of the disease between individuals, but no particular difference between the two groups. In fact, some mastitis was found in nearly all of the cows. 
Tests have been developed which are very reliable for detecting mastitis in its early stages. In the first group of 27 cows our men were able to detect the disease in nearly all animals on the project which had completed one or more lactations. The project is being continued with a new crop of animals - all first-lactation heifers. H. O. Henderson, E. N. Moore, A. H. VanLandingham, and C. E. Weakley, Jr., are working on it.

\section{The Progeny Test Can Predict Butterfat Percentage}

By supplementing the information collected in this project with records obtained through the cooperation of the Ayrshire Breeders Association, it has been possible for G. A. Bowling and D. N. Putnam to develop several methods of predicting the transmitting ability of butterfat percentage by young bulls.

By the use of these methods, a dairyman can perdict with a fair degree of accuracy the average fat test of the daughters of a bull before these heifers come into production, or even before they are born. The methods involve the use of the average tests of the cows to which the young bull is bred, and certain production tests in the pedigree of the young bull.

These studies indicate that the best way to select a young bull is to choose one that is sired by a good proved sire and out of a cow that has one or more daughters with good butterfat records. It seems to us that the progeny test should be applied in determining the value of brood cows, just as the progeny test is also used to determine the value of a proved sire.

\section{Cause and Prevention of Oxidized Flavor in Milk}

Two years ago, in my first Epistle to the Farm, I reported the finding of our dairymen and chemists that vitamin $\mathrm{C}$ and carotene in the diet had the effect of preventing the development of "oxidized" flavor in milk. Since then W. C. Brown and R. B. Dustman have experimented with different grades of alfalfa hay in the ration. Now they report that when high-quality alfalfa is fed, neither vitamin $\mathrm{C}$ nor carotene supplements are needed to prevent development of that off flavor that comes from contact of milk with certain metals like copper or iron.

Now these experimenters are working on other clues. They have a hunch that the kind of fat the cows get in their ration may have something to do with making milk susceptible to oxidized flavor development. To test out this theory they are putting the milk from different cows through many chemical tests.

Some day, maybe, milk will give up its secret. 


\section{PLANT DISEASES}

\section{Fruit and Leaf Injury from Spraying}

This business of testing many sprays for both their injurious and beneficial effects on fruit and foliage is a difficult one because there are so many on the market. On apples the so-called "neutral" coppers showed little promise. The non-injurious ones had little fungicidal value, while the more potent fungicides were as injurious as Bordeaux mixture and much costlier. The reverse is true on cherry. A number of these coppers are as effective as Bordeaux in controlling leaf spot and much less injurious to fruit and foliage. They are superior to lime sulphur in effectiveness against cherry leaf spot.

C. F. Taylor is trying out different strengths of Bordeaux on apples in an attempt to find a concentration that will provide fungicidal effectiveness and a minimum amount of fruit russet and at the same time prevent injury to the leaves from added insecticides containing arsenates.

\section{Black Rootrot in the Apple Orchard}

After some years we are still studying the behavior of Xylaria mali, the fungus responsible for black rootrot in apple orchards. One of the new ways C. F. Taylor is experimenting with is the system of water culture that you read about now and then. It is just another way of observing the disease when it is introduced into the roots of healthy seedlings.

\section{Internal-Bark Necrosis of Apple}

This disease, which was briefly described in Bulletin 260, continues to harass orchardists in certain sections of the state. Peach trees, too, have suffered from the same disease when situated in apple orchards where bark necrosis occurs.

The nature of the disease has been pretty well explored by our workers, but control measures still are lacking. Right now A. Berg and Genevieve Clulo are experimenting with boron to see if the lack of this little-known element has anything to do with the prevalence of this disease.

\section{A Rust-Resistant Red Cedar}

The red cedar is a useful as well as ornamental tree, and we would encourage the development of varieties that resist the rust disease that attacks apples, too. Well, we think we have got to first base in finding a resistant red cedar. Anthony Berg is propagating one such variety by grafting, and certain nurseries will probably look after its increase on 
a commercial scale. Later some specimens will be farmed out to localities in the country (I mean the U. S.) where the rust is important. There these trees will be tested to different strains of rust to see if they can take it without passing the disease on to the apple tree.

\section{What Causes Potato Blue Stem?}

After repeated tests, carried out over several seasons, with potato plants sereened and caged so that no insect could touch them, we are convinced that the potato wilt (blue stem) disease is carried by insects. But from where? We don't know. J. G. Leach and J. R. Mullin have suspected aster yellows, but so far they haven't been able to transmit that virus to potatoes via the insect or any other route. When we find the cause of the disease, we can begin to work on control measures.

\section{Vitamin $\mathrm{A}$ and the Common Cold}

Are West Virginia boys and girls eating the right foods, and enough of them? Miss Hazel Cameron, our nutrition specialist, with the help of the Student Health Service of the University, studied the blood samples of 115 students in the fall season, and again in midwinter. Haemoglobin determinations, counts of red and white blood cells, and other readings were made, and the dietary history was taken in each case.

Among other obscrvations she found that haemoglobin values were low in both men and women. This suggests that the diet had been low in iron and copper or maybe both. Besides, more haemoglobin showed up in the winter than in the warmer weather of fall. It is possible that the diet of the students while at the University was more adequate than it had been at home; or else the habits of eating and living had improved since coming to school. It should be remembered that these stridies were made on first-year students.

If food likes and dislikes play any part in the low haemoglobin values observed, these should show up in studying the dietary listory of each student. Miss Cameron did note that the reserve of vitamin A was somewhat better in women than in men. Possibly the girls are eating more fruits and vegetables than the boys.

\section{An Important Discovery in the Healing of Rickets}

In the process of healing rickety bones of white rats into normal ones, Miss Cameron, working with G. S. Dodds of the University School of Medicine, has found that the surplus of cartilage, so apparent in advanced cases of the disease, gradually disappears. In its place a new tissue forms which eventually hardens into new, normal bone.

I think it is significant that this Station should be the vehicle for a 
piece of research that has attracted the attention of the medical world. The clinicians have been able to use our observations in handling human cases of rickets.

\section{ENTOMOLOGY}

\section{Weather Records and Insect Control}

This Experiment Station has been spending many years studying the behavior of orchard and garden insects under different weather conditions. Why? Well, the insect problem is one of the limiting factors in fruit and vegetable production. The more we know about the lives of the bugs that destroy our crops, the closer we can come to destroying those bugs.

For instance, just when to begin a spray schedule depends entirely on the time when the insect is expected to appear in greatest numbers. That is why temperature readings have to be kept constantly. Those records make prediction possible, too, and take the guesswork out of spray-timing operations.

Take the bean beetle. We have learned a great deal about his expected abundance because we have observed temperature changes for so long. Be the winter severe or mild, what really matters is the kind of spring that follows. An early or an irregular spring will play hob with any beetle carryover. But a mild winter, plus a late spring (after mid-April), will set up ideal situations for the survival of an injurious population of that garden pest.

As for other insects, we can report that winter mortality is due usually to a set of conditions instead of one unfavorable factor. The favorable and the unfavorable conditions and combinations must be established with great care, over many years, for each species of insect. Even such seemingly distant factors as soil moisture, dates and amount of snowfall, and persistence of snow and ice - all these must be studied without a let-up, if we are to find effective and efficient ways of reducing the insect menace in orchard and garden.

\section{Ants vs. Codling Moths}

The codling moth continues to be the apple orchard's most important enemy, and fruit growing will be relieved of a heavy burden when that insect is put out of commission. Naturally, many experiment stations are working at solutions of the problem, and not the least among these is the West Virginia Station. In this project our efforts have been devoted largely to studying the nature of the insect and recording the percentage of infested fruits for different broods in each year. But 
that's not all by any means. Edwin Gould and L. M. Peairs have found beyond question that parasites and predators play a very appreciable part in keeping the moth population down. And we have new evidence on the effectiveness of tree banding.

Speaking of trap bands, I can report that in a special study devoted to ten apple trees, we discovered that more than 90 percent of the worms that stayed on the trees could be captured in the treated bands. And of the larvae that managed to get away from the trees, more than fourfifths were captured by predators.

Evidence is piling up that predators do more damage to codling moths than parasites do. And we note that ants are the most important of the predators. So now we are investigating ant life in the hope of finding the most useful species of this creature, which most of us pay no attention to except when it bites. In fact, we are studying what effect different cover crops, cultivation, and other orchard practices may have on ant populations. Codling-moth larvae make a tasty dish for the ant, and we are observing other food habits, too, of this predator.

Now cultivation has a way of breaking up the anthill, just as the plough once shattered a mouse's nest on Robert Burns's estate. That accident touched a tender spot in the poet's heart. Who knows but that, some day, the orchardist will be more tolerant of the ant and spare that hill, once he knows the value of the lowly forager?

\section{What About Non-Poisonous Sprays?}

Our research with different spray materials points to nicotine compounds as most effective in controlling codling moth. But as long as the cost is out of proportion, we can't recommend them. Arsenate of lead, the usual standby, in a schedule of four or five cover sprays, did not equal nicotine combinations applied in 11 cover sprays, but the arsenate was by far the best material tested when all materials went through an equal number of applications. The long and short of it is that the nonpoisonous insecticides are not yet developed to the point where they are commercially acceptable in the Cumberland-Shenandoah region. As a matter of fact, as long as fruit-washing is practiced, and the tolerance of residues is not held too low, there is less need for substitutes for the poisonous sprays. Just the same, we are keeping up with our search for safe, economical, and effective substitutes.

\section{ECONOMICS}

\section{Cooperative Buying in West Virginia}

It appears that three important problems confront farmers' purchasing co-ops in the state: (1) determination of effective means of 
organization, management, and financing; (2) establishment of an efficient operating policy with respect to problems of purchasing, sales, and accounting; and (3) setting up measurements for determining the effectiveness of present organization and operating policies.

Cooperative purchasing in this state is carried on mainly through the Cooperative Farm Services and its branch warehouses. Our study has been completed. In his report (Bul. 297) M. A. Abrahamsen points out that there is no justification for cooperative associations in the state deviating from established cooperative principles and that it is imperative for the Cooperative Farm Services to give immediate attention to the following factors: (1) complete reorganization, in order to associate membersihp, management, and ownership with the same individuals; such reorganization may be effected through either (a) remodeling the branch warehouse basis of organization ol' (b) incorporating each branch warehouse as a separate cooperative association; (2) calling preferred stock and providing for the establishment of a permanent financial policy designed to secure operating funds primarily from member patrons; (3) establishing purchasing and sales policies designed to meet the specific needs of farmers and to serve as the basis for sound operating practices; and (4) completely revising the existing accounting and auditing procedure in order that "measuring-sticks" may be set up to check efficiency and evaluate performance.

\section{Organization and Operation of Livestock Marketing Agencies}

Go back only ten years, and you will find that many important economic changes have contributed to the problems of livestock marketing in the state. There is greater use of trucks; direct marketing has increased; and the auction system has grown.

W. W. Armentrout and M. A. Abrahamsen have undertaken to visit local, state, and regional livestock coops as well as livestock auctions and independent local buyers. Here's the plan:

(1) Learn about the historical development and the prevailing market conditions in their relation to the agencies that serve the farmers.

(2) Appraise the organization set-up and the operating policies of local, state, and regional cooperative marketing associations.

(3) Evaluate the effect of the growth of auctions on returns to farmers and on other marketing agencies.

(4) Determine the relation of various types of independent buyers in the livestock marketing field.

(5) Appraise the attitude of stock farmers toward existing marketing agencies now serving farmers. 
When you consider that one-third of the state's cash farm income comes from the sale of livestock, you begin to realize that adequate marketing facilities are most important. This study should go far toward evaluating the present marketing situation and point the way toward improved policies and practices.

\section{Pasture Improvement in an Experimental County Program}

The study of the effectiveness of the provisions included in the Upshur County experimental program, which I reported in my first Epistle, has included, for comparative purposes, studies in three other counties situated in the same type-of-farming area-Braxton, Harrison, and Lewis. This study of farm organization in the north-central pasture area now includes data on six labor-income surveys, analysis of 768 farm business records, and detailed information about the operation of the Agricultural Conservation Program in those counties. The latter has to do with land use, practices carried out, payments made, and the extent of participation in the programs by farmers. More than 8,600 farms were involved in the study, which is carried out by F. D. Cornell, Jr., in cooperation with the Federal Bureau of Agricultural Economics.

As for Upshur County, we believe that a real achievement in pasture improvement can be credited to the experimental program.

In the entire county, where little or no pasture improvement work was done in 1937, there was a total of 2,312 units of improvement practices for which ACP payments were made in 1938. The second year of the experimental program shows even better results. In 1939 there was a total of 5,797 units of pasture improvement practices performed by approximately 1,100 farmers. In carrying out these practices in 1939, Upshur County farmers applied the equivalent of 2,931 tons of ground limestone, 85 tons of triple superphosphate, and 23 tons of 20 percent superphosphate on pastures.

Pasture improvement is of necessity a rather slow and gradual process. The full benefits of improvement practices are not and cannot be realized in a single season. But, within the next few years, distant pastures in Upshur County will not only look greener, they will be greener.

\section{Economic Development Under the Soil Conservation Program}

Field records were taken again in the Roane and Wirt area in 1939 on the same farms studied in 1934 and reported in Bulletin 269. These data are being summarized by F. D. Cornell, Jr., and the study of the Spencer area will be closed with the publication of the final report.

Also for the fifth time we have made a yearly study of the same 943 
farms in seven soil-conservation demonstration areas in an effort to measure the progressive economic effect of planned programs of conservation of soil and water.

The Jackson and Marshall County reports have been published as Bulletins 291 and 293. E. C. Weitzell is the author. The Harrison report should be out some time this year. All these carry information about :

(1) Technical description of agriculture within the demonstration areas.

(2) Business analysis of the several types of farming, pointing out the management practices that must be recognized and considered under a soil-conservation regime.

(3) Progress of the soil-conservation programs in terms of changes in land use, eropping practices, fertility practices, and yields.

\section{Profitable Orcharding in the Eastern Panhandle}

Sixty commercial orchards have been put through the mill for intensive study of operating costs and returns as related to soil types; cultural practices; packing, storing, and marketing methods; variety performance; and so on. A year ago we published a Nimeographed Circular (No. 39) by David Volkin and M. A. Abrahamsen on the operating costs for 1938 of 24 packing houses handling about one-third of the commercial apple crop in West Virginia. We found that 68 percent of all fruit was packed, 23 percent graded out as canner, cider, and bulk, and 9 percent was shrinkage. Of the packed fruit, 68 percent graded U. S. No. 1 or better, 19 percent utility, and 17 percent a combination of the two grades.

And we studied the relation of fruit production to packing costs. We found, among other things, that whenever the volume of bulk, canners, and ciders increased as much as 7 percent of the orchard's total volume, the cost of packing rose by a cent a bushel.

So you see it costs money to raise the cheaper stuff.

When we examined different packing costs, we found that labor made up 59 percent of all costs, depreciation and repairs 16 percent, supervision and administration 8 percent, utilities, taxes, and insurance 6 percent, and the rest (unclassified) 11 percent. Packing-house costs make up 15 to 20 percent of the total costs of apple production, and anything we can do to lower packing costs should add to the efficiency of apple production. 


\section{FORESTRY}

\section{A New Service to Forest Landowners}

The forest is West Virginia's largest renewable secondary resource, and the future of her civilization will hinge to a very considerable extent on how well her people treat this resource.

Since 1937, this division has launched an enterprise in forest management that is unique in the annals of the Nation's forest industry. In these few years, significant strides have been made. Let me illustrate:

It is not enough to know that forest land has been mismanaged for many decades or even to know how to manage this land in such a way that it will contribute more to the profit of its owners and to the general public. Even though the timber owner may be thoroughly familiar with the operations essential to woods management, he is seldom able to produce, to cut, and to market his crop without help from skilled workers who have the equipment that can handle such heavy objects as sawlogs. Heretofore the work of cutting trees for commercial use has been left to operators who were not primarily engaged in making money for the farmer. The personal profit motive on their part has been responsible for much of the widespread devastation of forest land and even to pessimism on the part of the forest landowner.

The foresters of the Agricultural Experiment Station under W. C. Percival's direction have been experimenting with a new organization and have developed a type which is now providing a forest management service to private landowners on a practical basis. This organization has been incorporated under the cooperative marketing laws of West Virginia under the name, the West Virginia Forest Products Association.

The landowner member now either can get any single item of service he needs, or he can employ the Association to give complete land-management service. This includes making a survey and an inventory of the land and standing timber, casting the survey data together with the landowner's objectives into practical management plans, making and supervising timber-cutting and hauling contracts, and selling the wood on the highest available market. How? By the joint supervision of an experienced woods operator and a technically trained forester.

This outfit is now serving the owners of about 40,000 acres of timberland situated in six counties: Braxton, Monongalia, Nicholas, Preston, Webster, and Wetzel. It started in Preston in 1937. The best indication of its usefulness to farmers and other landowners is the extent to which they have taken advantage. The volume of business handled by the Association for its members has risen from $\$ 2,000$ the first year to $\$ 22,000$ the third year and it may be near the $\$ 40,000$ mark in 1940 . 
The Association is still on an experimental basis, but its management fees, derived only from the sale of products, are going far toward paying its way, and it seems likely that this new service to timberland owners will soon be on a self-supporting basis.

This organization is an entirely new development in the United States, and other states are watching it closely. There are many problems yet to be solved, and continued and enlarged research is necessary to accomplish this end.

\section{Different Trees, Different Litters}

For a long time men have been aware of chemical and physical differences in the litter under different trees. Now they are beginning to recognize the importance of the litter in determining how fast trees grow. Under some forest trees like the evergreens, pine, spruce, and hemlock, the litter rots very slowly. The mineral nutrients in the litter are released slowly and this, of course, slows down their growth rate. That's why studies have been made on the rotting of leaves of many trees.

E. H. Tyner and W. M. Broadfoot have found that wide differences in the amount of rotting exist between mature leaves of different species. This disintegration of fallen leaves is due to bacteria and fungi which are being studied by E. A. Marten. When we know more about the conditions which bring about the decay of leaves we can speed up the formation of humus in the soil. Also, we hope to determine the effect of various tree species on soil properties and the effect of site quality on the growth rates of our desirable forest-tree species.

\section{Tree Growth and Mine Props}

The Forestry division of the College of Agriculture is active in research work as well as in college instruction. Now in the field of forestry, especially as it relates to this Mountain State, research must concern itself with industrial as well as farm problems. And with the limited funds and personnel at our disposal, we have undertaken a number of projects in behalf of both agriculture and the state's mammoth coal industry.

One of the latter projects, begun in 1938 and already completed, involved an intensive study of tree growth on coal lands owned by four of the big coal companies in southern West Virginia. Our foresters studied average per-acre volume and gross and net volume growth per acre in terms of cubic feet, mine props, and board feet, and then determined growth percentages. They did this for the four important forest types in the counties of Logan, McDowell, Mingo, Raleigh, and Wyoming. 
The study of 990 sample tres and of 207 sample plots, carried out by Lowell Besley, reveals that the diameter growth of individual trees is better than expected, but the tree density on those lands is very low. That means that the stand per acre and therefore the growth per acre are not satisfactory when you take future needs into account. Also, the individual trees were often found rotten in the core. Likely that is the result of fire in the early years. And, we found that north and east slopes were far ahead of south and west slopes in encouraging growth and in maintaining a healthy condition of the stands.

\section{Weatherproofing and Fireproofing Wood}

For many years, wood used in exposed places has been treated with preservatives to make it resistant to decay. Recently some of the wood used in building houses and factories has been treated with fireproofing chemicals. With this growing use of chemical treatments for making wood resistant to both decay and fire, it is important to know the effect of the treatments upon the desirable qualities of the wood. A recent publication by H. D. Erickson deals with the effect of various chemicals on the swelling and the strength of wood. The results indicate that some chemicals affect these properties favorably while certain others have the opposite effect. This study lays the foundation for further work emphasizing chemicals now used in commercial treatments.

In other studies we have found that the rate of growth affects the hardness, the strength, the shrinkage, and the weight of yellow poplar. This is important for the farm woodlot owner who has marketable poplar in production. These results probably apply to other woods similar to poplar, too.

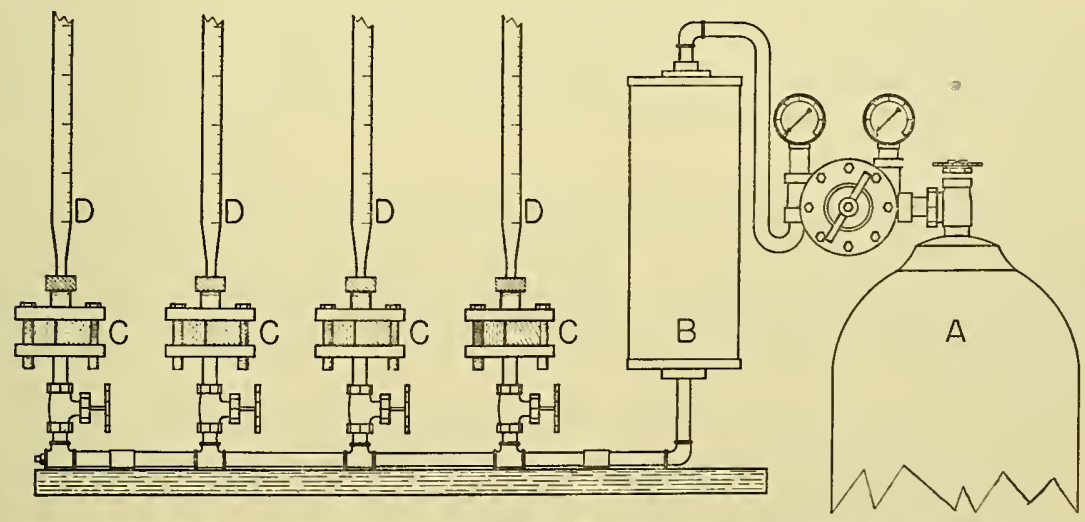

Apparatus for the study of permeability in hardwoods. The tank A supplies pressure, which is regulated by valves, to force the liquid to tank $B$ through the sections of wood $C$, which are clamped between disks. The flow of the liquid is measured in tubes $D$ and timed with a stop watch. 


\section{IN CONCLUSION}

What I have pointed out is representative of the large body of research carried on at the West Virginia Agricultural Experiment Station. Since 1888, when the Station was established, we have gone a long way. But we have much farther to go if we are to solve the problems that are continually arising on the farm.

Farm research is a long and involved and expensive business that must be done by a public institution. It involves the use of experimental equipment and it calls for a large, well-trained personnel that will not be pulled away by more attractive offers in other states or in industry.

Time is an essential in carrying research to the point where it will help the farmer increase his income. Land is needed by the West Virginia Experiment Station for extensive field tests. Buildings with wellequipped laboratories are badly needed at this Station. Large funds will have to be appropriated by our Legislature. For several years now, our State Legislature has been appropriating less and less for research in agriculture. This needs to be and must be changed if the farmers of West Virginia are to compete in the production and marketing of their products with the farmers of other states. I told you in my letter of introduction that we are trying to plug all the holes we can, but I'm sure you realize that materials and labor for doing this job are necessary, and these must be provided if the job is to be well done.

\section{STAFF CHANGES}

New appointments within our research staff during the two-year period 1938-1940 include L. F. Miller, assistant agricultural economist; W. M. Nelson, photographer; D. N. Putnam, assistant in dairy husbandry; T. D. Runnels, assistant in poultry husbandry; F. W. Schaller, assistant in agronomy; and David Volkin, assistant in agricultural economics.

Promotions include E. P. Brasher, assistant horticulturist; D. S. Brown, assistant in horticulture; W. H. Childs, assistant horticulturist; Genevieve B. Clulo, assistant plant pathologist; A. P. Dye, assistant horticulturist; W. C. Percival, forester; and R. H. Sudds, associate horticulturist.

During the same period the following have resigned: L. F. Herrmann and E. O. Leonard, assistants in agricultural economics.

Two deaths have occurred: those of L. M. Hill, assistant in plant pathology; and W. K. Lanham, assistant in agricultural economics. 


\section{PUBLICATIONS OF THE BIENNIUM 1938-1940 \\ BULLETINS AND CIRCULARS}

Bul. 287. A. R. Stanley. Physiological and serological studies of the soft-rot and colon group of bacteria. $36 \mathrm{pp}$. July 1938.

Bul. 288. F. J. Schneiderhan. Control of eherry leaf-spot in West Virginia. 13 pp. ill. July 1938.

Bul. 289. R. R. Robinson and W. H. Pierre. Response of permanent pastures to lime and fertilizers in 1930 to 1936. 48 pp. ill. August 1938.

Bul. 290. C. R. Orton. Epistle to the farm. The report of the director, West Virginia Agricultural Experiment Station, Morgantown, for the biennium 1936 to 1938 . $64 \mathrm{pp}$. ill. December 1938 .

Bul. 291. E. C. Weitzell. Certain economic aspects of agriculture in the Jackson County soil-conservation area. 56 pp. ill. July 1939. In cooperation with the Soil Conservation Service and the Bureau of Agricultural Economics, U. S. D. A.

Bul. 292. W. W. Armentrout and T. D. Johnson. Types of farming in West Virginia. 80 pp. ill. Aug. 1939. In cooperation with the Bureau of Agricultural Economics, U. S. D. A.

Bul. 293. E. C. Weitzell. Economic implications of soil conservation in Marshall County. 48 pp. ill. Aug. 1939. In cooperation with the Bureau of Agricultural Economics and the Soil Conservation Service, U. S. D. A.

Bul. 294. C. E. Weakley, Jr., and R. B. Dustman. The composition of different skeletal parts of experimental animals. 40 pp. Sept. 1939.

Bul. 295. C. V. Wilson and E. W. McComas. The relative merits of producing creepfed, feeder, and lot-fattened calves in West Virginia. $12 \mathrm{pp}$. Nov. 1939. In cooperation with the Bureau of Animal Industry, U. S. D. A.

Cir. 76. H. O. Henderson and G. Heebink. Raising dairy calves and heifers. 24 pp. ill. Nov. 1939.

\section{MIMEOGRAPHED CIRCULARS}

No. 32. Low-income farms in West Virginia. A symposium. August 1938.

No. 33. K. C. Westover, E. P. Brasher, R. S. Marsh, G. G. Pohlman, J. A. Rigney, and C. R. Burnham. Report of horticultural and agronomic experiments, Arthurdale Experiment Farm, Reedsville, West Virginia, in 1938. Januarj, 1939.

N.o 34. E. J. Wellhausen and J. L. Cartledge. Results of hybrid corn yield trials in West Virginia for 1938. February 1939.

No. 35. (A and B) M. A. Abrahamsen and W. K. Lanham. Apple-production costs and returns in the Eastern Panhandle of West Virginia. March 1939.

No. 36. R. S. Marsh and M. A. Abrahamsen. Apple varieties and the age of trees. March 1939.

No. 37. Lowell Besley. Preliminary rolume tables for some of the tree species used for pulpwood in Preston County, West Virginia. April 1939.

No. 38. Notes from the meeting on water resources in land use held March 24, 1939, at Elkins, West Virginia. April 1939.

No. 39. David Volkin and M. A. Abrahamsen. Packing-house operating costs in the Eastern Panhandle of West Virginia, 1938 crop year. Sept. 1939.

No. 40. E. J. Wellhausen. Results of hybrid corn yield trials in West Virginia for 1939. Jan. 1940.

No. 41. T. B. Clark, T. D. Runnels, and E. A. Livesay. Turkey production in West Virginia. April 1940. ill.

\section{SCIENTIFIC PAPERS}

No. 201. L. M. Hill and C. R. Orton. Microchemical studies of potato tubers affected with blue-stem disease. Jour. Agr. Res. 5\%, no. 5: 387-392. September 1, 193 . 
No. 202. F. D. Fromme and F. J. Schneiderhan. Studies of black rootrot of apple. Phytopath. 28, no. 7: 483-490. July 1938.

No. 204. L. H. Leonian and V. G. Lilly. Thiamin, its constituents, and the source of nitrogen. Phytopath. 28, no. 8: 531-548. August 1938.

No. 205. C. E. Weakley, Jr., and R. B. Dustman. Bilateral variation in the weight and composition of the long bones of experimental animals. Jour. Agr. Res. 58, no. 9: 711-716. May 1, 1939.

No. 206. D. S. Brown. A simpler and more rapid variation of the sodium cobaltinitrite method for the determination of small amounts of potassium. Ind. and Eng. Chem. (anal. ed.) 10: 652. November 15, 1938.

No. 207. W. C. Brown and R. B. Dustman. Oxidized flavor in milk: VI. A study of the relation of titratable acidity to metal-developed oxidized flavor in milk. Jour. Dairy Sci. 22, no. 1: 31-35. January 1939.

No. 208. L. M. Hill. A study of suberin and suberized deposits of diseased potato tubers. Phytopath. 29, no. 3: 274-282. March 1939.

No. 209. W. C. Brown, A. H. VanLandingham, and C. E. Weakley, Jr. Oxidized flavor in milk: VII. Studies of the effect of carotene and ascorbic acid in the feed of the cow on the susceptibility of the milk to metal-induced oxidized flavor. Jour. Dairy Sci. 20, no. 5: 345-351. May 1939.

No. 210. G. E. Yerkes (U. S. D. A.) and R. H. Sudds. Influence of stocks on performance of certain apple varieties. Proc. Amer. Soc. Hort. Sci. 36: 116120. 1938.

No. 211. R. H. Sudds and R. S. Marsh. Some results and suggestions regarding the use of calcium eyanamid on apples. Proc. Amer. Soc. Hort. Sci. 36: 36-40. 1938.

No. 212. D. S. Brown and R. H. Sudds. The removal of soot on apples grown in the bottomlands along the Ohio River in the Northern Panhandle of West Virginia. Proc. Amer. Soc. Hort. Sci. 36: 234-238. 1938.

No. 213. D. S. Brown. A preliminary report on a study of the nutrient level of orchard soils in the Eastern Panhandle of West Virginia and its relation to tree condition and productivity. Proc. Amer. Soc. Hort. Sci. 36: 45-48. 1938.

No. 214. L. H. Leonian and V. G. Lilly. Studies in the nutrition of fungi. II. Effect of inoculum upon the growth of the colony. Phytopath. 29, no. 7 : 592-6. July 1939.

No. 215. V. G. Lilly. Growth substances for fungi: II. Critical survey of literature 1936-37. Proc. W. Va. Acad. Sci. 12: 72-78. In W. Va. Univ. Bul. ser. 40, no. 5-I. Nov. 1939.

No. 216. V. G. Lilly and L. H. Leonian. Vitamin $B_{1}$ in soil. Science 89, no. 2309: 292. March 31, 1939.

No. 217. W. M. Broadfoot and W. H. Pierre. Forest soil studies: I. Relation of rate of decomposition of tree leaves to their acid-base balance and other chemical properties. Soil Sci. 48, no. 4: 329-48. Oct. 1939.

No. 218. R. L. Shirley and A. H. VanLandingham. Determination of uric acid in the mixed excrements of birds. A modification of the Fritz differential extraction method. Ind. and Eng'g. Chem., anal. ed. vol. 11: 381-3. July $15,1939$.

No. 220. V. G. Lilly. Fungi for thiamin (Vitamin $B_{1}$ ) assay. Proc. W. Va. Acad. Sci. 13: 72-77. In W. Va. Univ. Bul. 40 no. 10-I. April 1940.

No. 221. C. R. Burnham and J. L. Cartledge. Linkage relations between smut resistance and semisterility in maize. Jour. Amer. Soc. Agron. 31, no. 11: 924-33. Nov. 1939.

No. 222. T. B. Clark. The relation of production and egg weight to age in White Leghorn fowls. Poult. Sci. 19, no. 1: 61-66. Jan. 1940.

No. 223. G. S. Dodds and Hazel Camejon. Studies on experimental rickets in rats: III. The behavior and fate of the cartilage remnants in the rachitic metaphysis. Amer. Jour. Path. 15, no. 6: 723-740. 2 plates. Nov. 1939.

No. 224. R. B. Dustman and I. J. Duncan. Red color in apples. Science 90, no. 2332:233. Sept. 8, 1939. 
No. 227. L. H. Leonian and V. G. Lilly. Studies on the nutrition of fungi: IV. Factors influencing the growth of some thiamin-requiring fungi. Amer. Jour. Bot. 27, no. 1: 18-26. Jan. 1940.

No. 229. R. B. Dustman and I. J. Duncan. The effect of certain thiocyanate sprays on foliage and fruit in apples. Plant Physiology 15: 343-348. (with one colored plate: contrast of apples on ground, and in tree) April 1940.

\section{CURRENT PROJECTS}

\section{AGRONOMY AND GENETICS}

Variety testing of corn, wheat, oats, and soybeans (S 6)

Alfalfa investigations (S 10)

Crop-rotation experiments (S 11; coop. Horticulture)

Sweet-clover investigations (S 13; coop. Agricultural Chemistry)

Crop responses to various fertilizers ( $\mathrm{S}$ 14)

Different varieties of pasture for milk production) (S 22; coop. Dairy Husbandry)

Corn genetics and breeding (B J 3; coop. U. S. D. A.)

Forest soils (B J 9 ; coop. Plant Pathology)

Investigation of soil slips in West Virginia (B J 15 ; coop. State Road Commission)

Reclaiming eroded soils (B J 17 ;coop. Forestry \& Soil Conservation Service, U. S. D. A.)

Effect of fertilizer treatments and cropping systems on yield and quality of tobacco (B J 19; coop. U. S. D. A.)

Breeding tobacco for resistance to rootrot and for high yield (P 1; coop. Plant Pathology \& U. S. D. A.)

Soil acidity and plant growth (P 2)

Plant nutrient availability studies ( $P$ 29)

West Virginia pastures (P 30; coop. Dairy Husbandry, Animal Husbandry, \& U. S. D. A.)

\section{ANIMAL HUSBANDRY}

Effect of rations and methods of feeding grain on egg production (S 15)

Battery rations for growing chicks ( $\mathrm{S}$ 17)

The time factor in egg production (A 8)

Improving market qualities of turkeys by cross-breeding (B $\mathrm{J}$ 5)

Selection of breeders in relation to longevity of progeny in S. C. White Leghorns (B J 13)

Breed as a factor in sheep production and quality of products produced ( $P$ 5 ; coop. U. S. D. A.)

Effects of early and late treatment for gastro-intestinal parasites on growth and finish of lambs ( $P$ 6)

Beef cattle husbandry investigations re.. lating to feeding and fattening of steers and heifers (P 7; coop. U. S. D. A.)

\section{CHEMISTRY (AGRICULTURAL)}

Miscellaneous chemical investigations ( $S$ 5)

Pigmentation and ripening of fruits (A 3)

High and low protein diets in relation to mortality and fecundity in White Leghorns (A 7; coop. Animal Hus. bandry)

Effect of method of storage of hay on its nutritive value for sheep and beef cattle (B J 24; coop. Animal Husbandry)

Relative values for growth of the proteins of a number of feeds used in poultry rations (P 4; coop. Animal Husbandry)

Variability in composition of different skeletal parts of experimental animals (P 20)

Corn-silage studies (P 22; coop. Animal Husbandry)

\section{DAIRY HUSBANDRY}

Growth study with Ayrshire cattle (S 21)

Water consumption of dairy animals (S 23)

Feeding as a contributory factor to the development of mastitis (B $\mathrm{J} 10$; coop. Animal Pathology and Agricultural Chemistry)

Economic study of White Leghorn and New Hampshire breeds of chickens for meat and egg production (B J 20; coop. Animal Husbandry \& Agricultural Economics)

Effect of low-calcium and low-phosphorous rations on growing dairy heifers (P 8; coop. Agricultural Chemistry)

Transmission of milk and butterfat production and body conformation by dairy sires (P 14 ; coop. U. S. D. A.)

Causes and methods of prevention of oxidized flavors in milk (P. 23; coop. Agricultural Chemistry)

Causes for poor quality of cream transported in less than car lots (P 24) 
Comparison of alfalfa and timothy hay with and without corn silage for dairy cattle (P 25; coop. Agricultural Chemistry)

\section{ENTOMOLOGY}

Miscellaneous insect and insecticide studies (S 24)

Relation of temperature to insect life (A 1)

Biological and mechanical control of codling moth (B J 1; coop. U. S. D. A.)

The biology and control of insects of major importance in commercial orchards in West Virginia ( $\mathrm{P}$ 9; coop. Maryland, Pennsylvania, Virginia, \& U. S. D. A.)

\section{FARM ECONOMICS}

Regional adjustments in farming (B J 4 ; coop. Agronomy \& U. S. D. A.)

Farm organization, soil and pasture-management practices, and applicability of Agricultural Conservation Programs in a self-sufficing small-farm area in West Virginia (B J 18; coop. A. A. A. \& B. A. E., U. S. D. A.)

Effect of ownership on conservation, development, and use of agricultural lands in West Virginia (B J 21)

Economic and social effects on farms resulting from operation of a definitely planned program of soil conservation (P 12; coop. Soil Conservation Service, U. S. D. A.)

Factors involved in profitable orcharding in the Eastern Panhandle of West Virginia (P 27; coop. Horticulture) Cost of milk production ( $\mathrm{P} 28$; coop. Dairy Husbandry)

\section{FORESTRY}

Current growth rates on hardwood lands cut over for mine materials in southern West Virginia (S 35)

Profitable tree forms (S 37)

Forest plantations in West Virginia ( $S$ 38)

Conservation of farm woodlands in West Virginia through sustained-yield management and marketing practices ( $\mathrm{B}$ J 7 ; coop. U. S. Forest Service)

Directional permeability of some Appalachian hardwoods (B J 11)

Effect of black-walnut trees and their products on vegetation (B J 22)

\section{HORTICULTURE}

Miscellaneous horticultural investigations (S 27)

Cultural treatments and fertilizers for fruits (S 28)
Variety tests of tree and small truits (S 29)

Training and pruning fruit trees (S 30)

Production of farm and garden crops on subsistence homesteads (S 32; coop. Agronomy)

Productivity of carnations as affected by age of eutting and time of planting (S 34)

Fertilizer and cover-crop studies with asparagus (S 36)

Hardiness studies of fruit buds of peach (A 4; coop. Agricultural Chemistry)

Selection, breeding, and propagation of low-bush blueberry (B $\mathrm{J}$ 12)

Effect of cultural practices and orchardsoil management on soil moisture and availability of plant nutrients, particularly potassium, to fruit trees (B $\mathrm{J} 16$; coop. Agronomy)

Nutrient studies with peaches with particular reference to potassium (B J 23)

Green-manure rotations for upbuilding and maintaining soil fertility in vegetable crop production ( $P$ 11)

Improvement of fruit-tree rootstocks ( $P$ 16 ; coop. U. S. D. A.)

Climatic and soil factors affecting fruit production in West Virginia (P 17)

\section{PLANT PATHOLOGY AND BACTERIOLOGY}

Forest-tree diseases (S 18)

Miscellaneous plant-disease investigations (S 19)

The effect of environment upon morphology and parasitism in fungi (A 6)

Insect transmission of plant diseases (A 9)

Anatomical and histological changes in diseased plants (A 10)

Nature and effect of substances which induce or stimulate growth and sexuality in fungi (B $\mathrm{J} 2$ )

Apple, fruit, and leaf injury caused by spraying and unfavorable weather conditions (B J 6; coop. Experiment Stations of Virginia, Pennsylvania, and Maryland)

Potato wilt disease of unknown nature (B J 8)

Adequacy of nutrition in native West Virginians with respect to vitamins A and $B$ and iron (P 15)

Fusarium wilt of watermelon (P 18; coop. Agronomy)

Apple measles (P 19)

Black rootrot of apple ( $P$ 21)

Histology and bone growth in vitamin deficient animals (P 26; coop. School of Medicine) 
